This item was submitted to Loughborough's Research Repository by the author.

Items in Figshare are protected by copyright, with all rights reserved, unless otherwise indicated.

\title{
Scoping review to draw together data on child injury and safeguarding and to compare the position of England with that in other countries
}

\section{PLEASE CITE THE PUBLISHED VERSION}

https://www.gov.uk/government/uploads/system/uploads/attachment_data/file/182284/DFE-RR083.pdf

\section{PUBLISHER}

Department for Education (c) Childhood Wellbeing Research Centre

\section{VERSION}

VoR (Version of Record)

\section{PUBLISHER STATEMENT}

This work is made available according to the conditions of the Creative Commons Attribution-NonCommercialNoDerivatives 4.0 International (CC BY-NC-ND 4.0) licence. Full details of this licence are available at: https://creativecommons.org/licenses/by-nc-nd/4.0/

\section{LICENCE}

CC BY-NC-ND 4.0

\section{REPOSITORY RECORD}

Munro, Emily R., Rebecca Brown, Joe Sempik, Harriet Ward, and Charlie Owen. 2019. "Scoping Review to Draw Together Data on Child Injury and Safeguarding and to Compare the Position of England with That in Other Countries". figshare. https://hdl.handle.net/2134/18191. 


\section{scoping review to draw together data on child injury and safeguarding and to compare the position of England with that in other countries}

Emily R. Munro, Rebecca Brown, Joe Sempik and Harriet Ward* with Charlie Owen**

\section{Childhood Wellbeing Research Centre}

*Centre for Child and Family Research, Loughborough University

* * Thomas Coram Research Unit, Institute of Education, University of London

Department for Education 
This research report was commissioned before the new UK Government took office on 11 May 2010. As a result the content may not reflect current Government policy and may make reference to the Department for Children, Schools and Families (DCSF) which has now been replaced by the Department for Education (DFE).

The views expressed in this report are the authors' and do not necessarily reflect those of the Department for Education. 


\section{Contents}

Chapter One

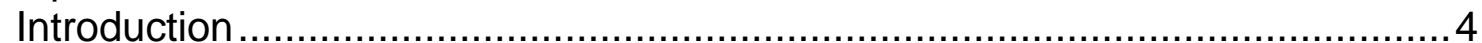

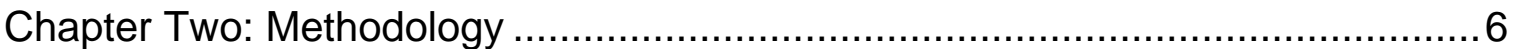

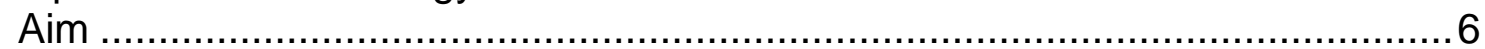

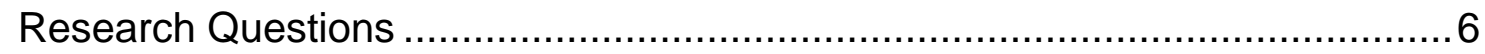

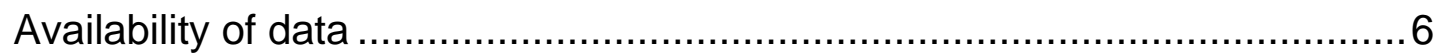

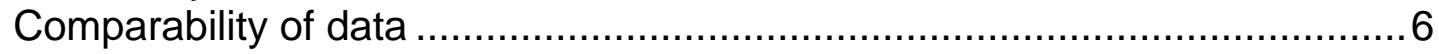

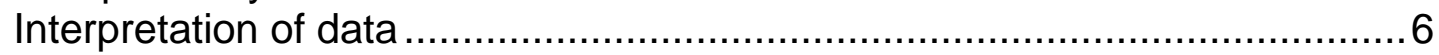

The Electronic Database ……............................................................ 10

Chapter Three: Safeguarding processes and procedures and definitions of child

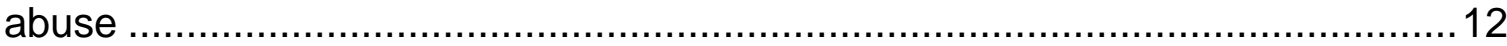

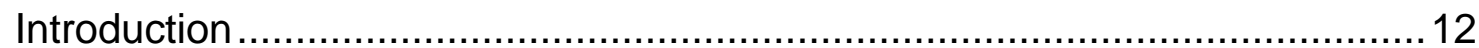

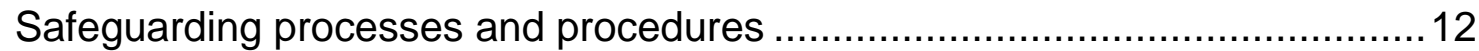

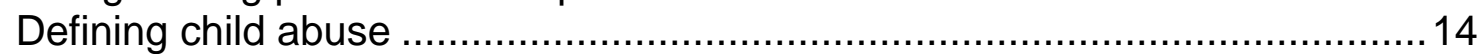

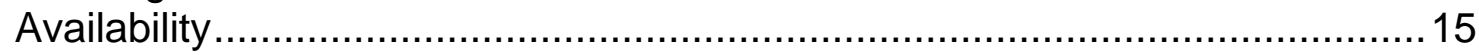

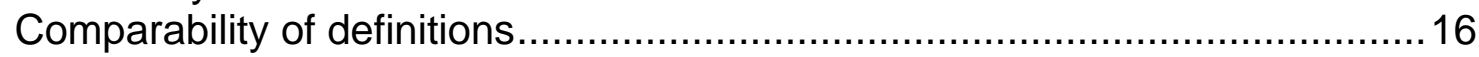

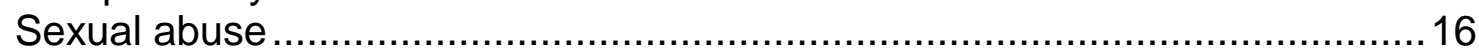

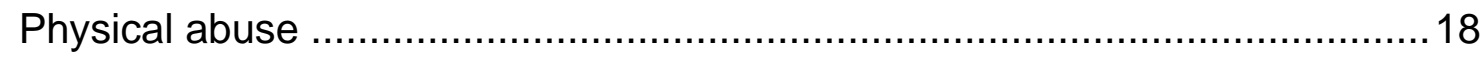

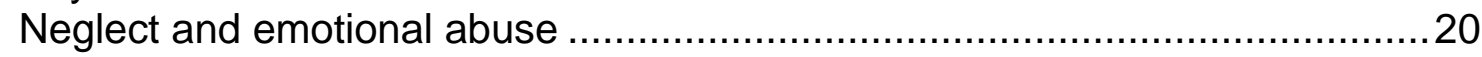

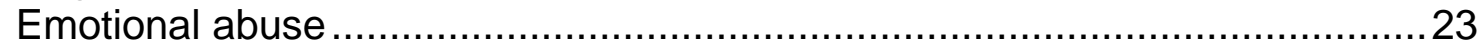

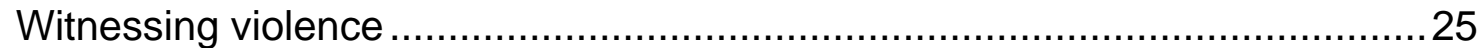

Number and proportion of cases by abuse type shown in national statistics ...27

Chapter Four: Availability and comparability of data on safeguarding children ...30

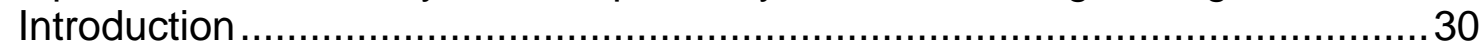

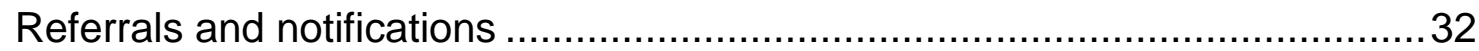

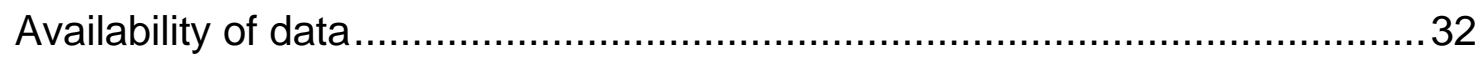

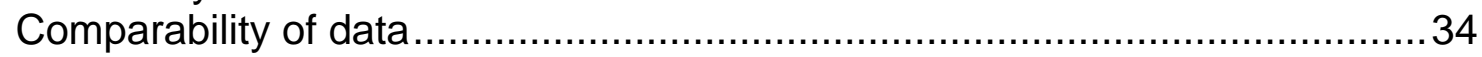

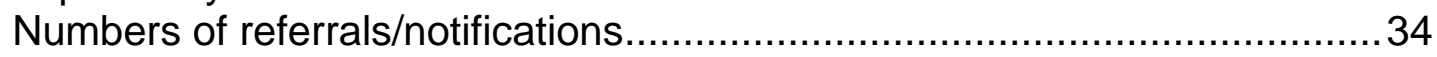

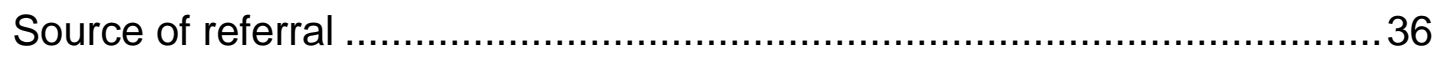

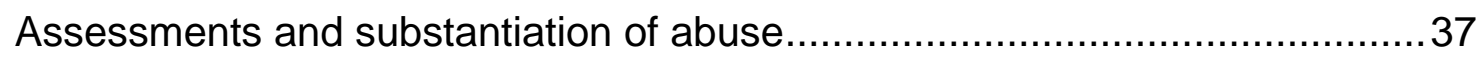

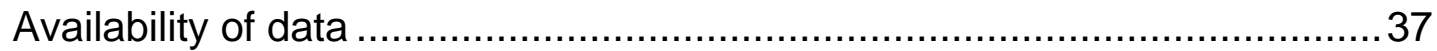

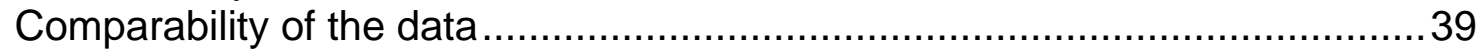

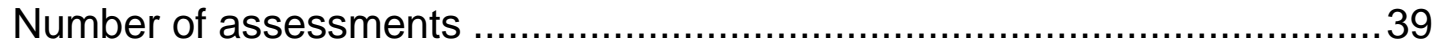

Outcome of assessments.................................................................. 40

Provision of community-based services (largely for children remaining with their

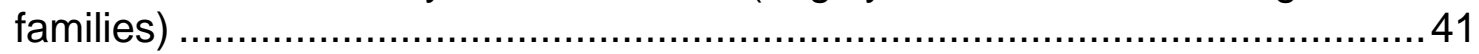

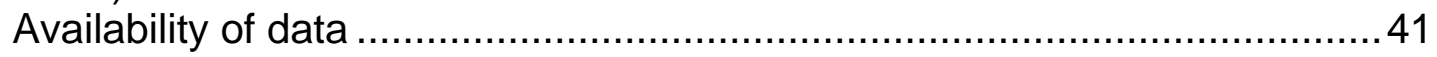

Looked after children/ out-of-home care .................................................. 42

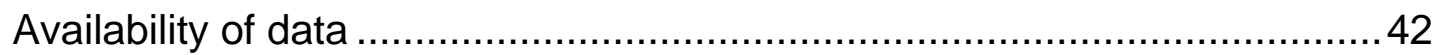

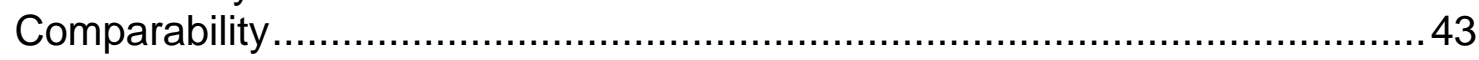

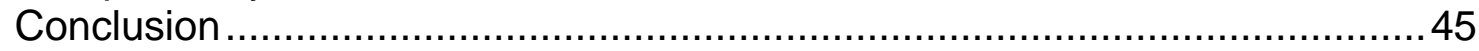

Chapter Five: Internationally collated data on child death and injury .................46

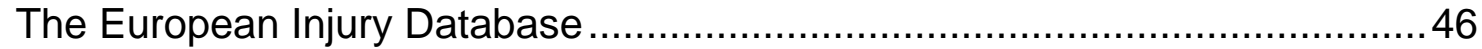

Infant mortality - All causes ................................................................ 47

Injuries and 'other' causes of death in children aged under five ....................48

Negligence, maltreatment or physical assault ............................................49

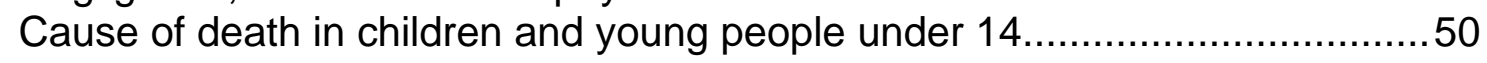

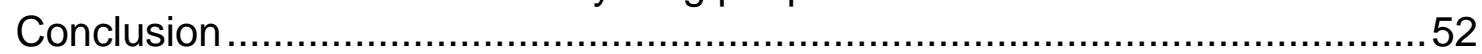




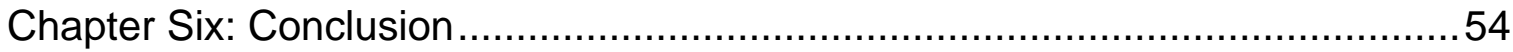

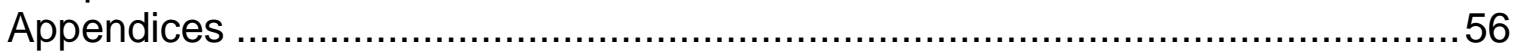

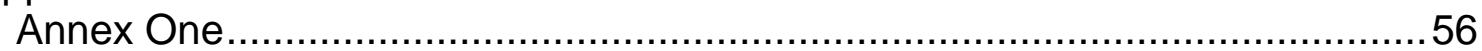

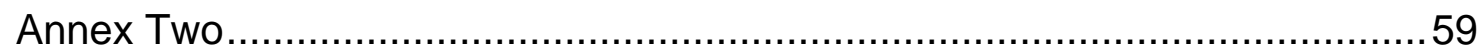

Safeguarding policies and procedures by country ........................................59

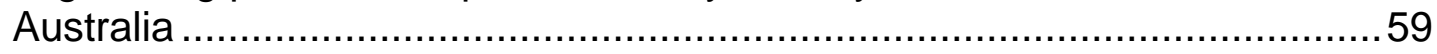

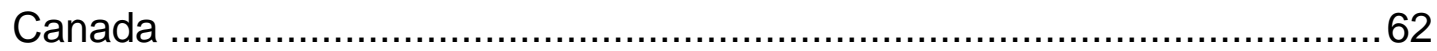

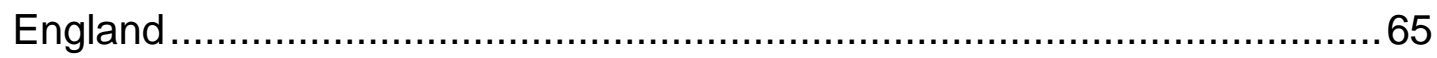

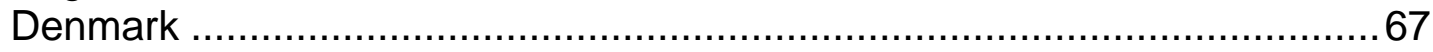

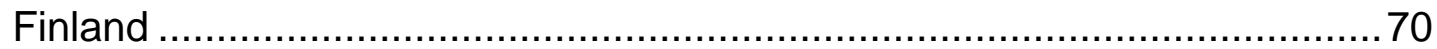

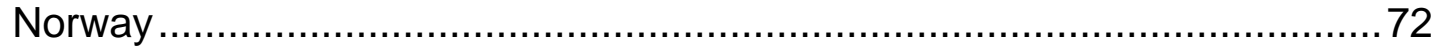

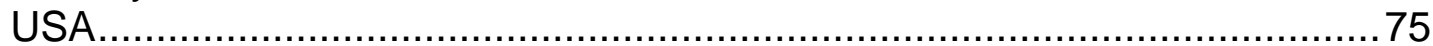

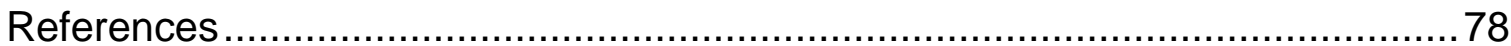

\section{List of tables}

Table 2.1: International Organisations and Databases Used in the Initial Search.7

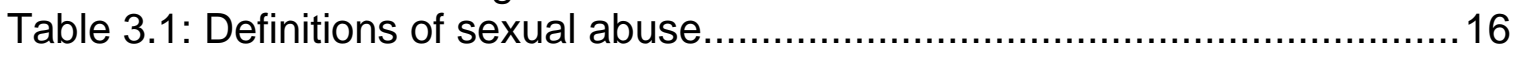

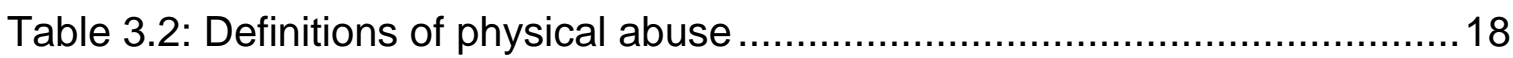

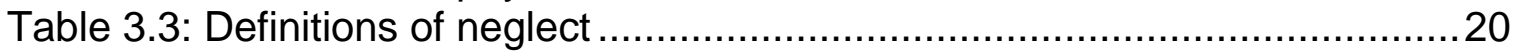

Table 3.4: Definitions of emotional/psychological abuse ................................2 23

Table 3.5: Definitions of witnessing violence ..............................................2 25

Table 3.6: Number and proportion of cases by abuse type ……......................2

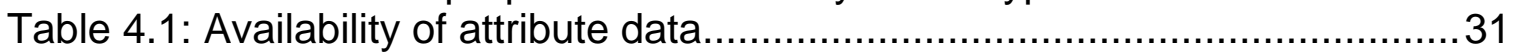

Table 4.2: Referral/notification data items collected ........................................ 33

Table 4.3: Rates of referral per 1000 in sample countries and percentage

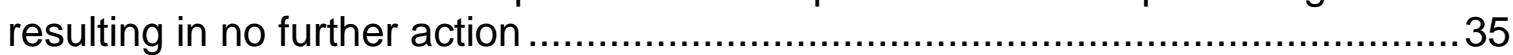

Table 4.4: Sources of referral to children's social care ..................................... 37

Table 4.5: Assessment and investigation data items collected by two or more

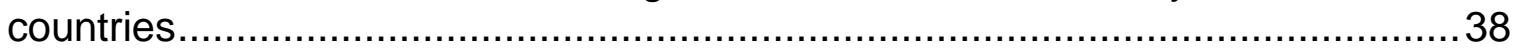

Table 4.6: Number and rate of assessments undertaken in sample countries ....39

Table 4.7: Substantiation of abuse ............................................................ 40

Table 4.8: Data items collected by two or more countries relating to communitybased services (children remaining with their families) .....................................4 41

Table 4.9: Number and rate of children subject to plans and services ...............42

Table 4.10: Data items collected by two or more countries relating to looked after

children/children in out-of-home care ............................................................ 43

Table 4.11: Number and rate of children in out-of-home care ...........................4 44

Table 4.12: Number and rate of children entering care for the first time in a given

year (new entrants) ............................................................................. 44

Table 5.1: Infant mortality rate (probability of dying between birth and age one per 1,000 live births), 2008 .................................................................................. 48

Table 5.2: Under five mortality (probability of dying by age 5 per 1,000 live births),

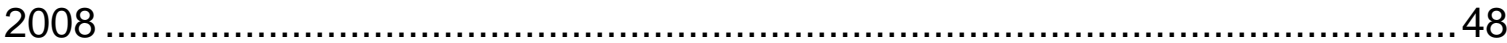

Table 5.3: Cause of death among children aged under five due to injuries and 'other' causes, distribution of cases (\%), 2008 ............................................... 49 Table 5.4: Child death rates due to negligence, maltreatment or physical assault, children 0-19 years old 
Table 5.5: Estimated causes of death; persons aged 0 to 14 (rates per 100,000), 2004 51

Table 5.6: Ranking of all countries in the sample according to causes of death; persons aged 0 to 14, 2004 (ranked lowest to highest).... 52

\section{List of figures}

Figure 2.1: Summary of Method Used (comparison of international data on child protection) 7

Figure 1: Scope of the CIS-2008 


\section{Chapter One}

\section{Introduction}

Statistical data on the proportion of children identified as likely to suffer significant harm, cases of substantiated abuse and neglect and the number placed in public care vary between regions and countries, as do placement types and service responses. Comparing the situation in England with that elsewhere and exploring similarities and differences in the approaches adopted to safeguard children from harm allows current policy and practice to be benchmarked against others. Changes over time can also be monitored and lessons learnt from elsewhere (Munro et al., 2005; Stein and Munro, 2008). However, caution is needed to ensure that comparisons are valid. Consideration needs to be given to the differences in historical, social, cultural, political and economic context that influence developments in child welfare, as well as variations in definitions of key terms and concepts and in the availability, reliability and comparability of different datasets (Courtney, 2008).

To make meaningful comparisons of data on child death, injury and safeguarding, it is first necessary to ascertain what data are already routinely collected by different countries and how comparable these datasets are. In 2007 An Overview of Child Well-being in Rich Countries (UNICEF, 2007) indicated that limited work has been undertaken on this at an international level. Since then efforts have been made to explore the availability and comparability of child protection data from different countries; findings reinforce the challenges of doing so in practice (ChildOnEurope, 2009; ISPCAN, 2010). Building on this work, the study aims to explore the availability and comparability of data on safeguarding children from physical abuse, sexual abuse, emotional abuse, neglect and exposure to intimate partner violence and from child death and injury in seven countries.

Interpretation of data to compare the prevalence of abuse and neglect in England with other countries needs to be undertaken with caution. Consideration needs to be given to 'the mix of welfare provision between the state, the individual, the family and other sectors of provider' (Alcock, 2001) and legislative and policy 
developments that may influence how professionals respond to protect and promote the welfare of children. For example, research in England indicates that policies designed to promote early intervention and the integration of services have had an impact on the interpretation of terms such as 'children in need' (Ward et al., 2008). Quantitative findings will therefore need to be considered within a wider social policy context to facilitate understanding of whether variations between countries are a reflection of different historical traditions or the effectiveness of legislation, policy and practice (Hantrais, 2009; Munro and Stein, 2008).

The report presents the findings from a small scale scoping review undertaken between July and December 2010 to explore some of these issues. The next Chapter outlines the methodology in more detail. Chapter Three provides an overview of how differences in child welfare systems may influence data collection and comparability of data. It also examines the extent to which there is international consensus concerning what constitutes abuse and the impact that variations in operational definitions have upon the valid cross-national comparisons that can be drawn. Chapter Four explores the availability and comparability of data at each of the key stages in the child protection process from initial referral to placement in out-of-home care. It also presents data on key variables from countries in the sample. Chapter Five examines similarities and differences in rates of child mortality across countries and what conclusions can meaningfully be drawn from this. The Conclusion highlights the implications of the findings for English policy and practice and identifies areas for future research. 


\title{
Chapter Two: Methodology
}

\begin{abstract}
Aim
The overarching aim of the study is to scope the existing international data on safeguarding children from physical abuse, sexual abuse, emotional abuse, neglect and exposure to intimate partner violence and from child death and injury. The objective is to consider how different institutional and cultural approaches to safeguarding children and different forms of provision and support may influence trends in the incidence and nature of abuse and neglect and similarities and differences in the responses of public authorities.
\end{abstract}

\section{Research Questions}

The study focuses on ascertaining the availability of data on preventable child death and injury and safeguarding; and identification of a core set of variables to facilitate exploration of the comparability of these data. The following questions have been investigated:

\section{Availability of data}

What official statistics on preventable child injury and safeguarding are routinely collected by countries and how frequently is information collected? Is there a core set of variables that most countries tend to include in their statistical returns?

\section{Comparability of data}

What conceptual and definitional issues are encountered and need to be resolved to facilitate meaningful cross-national comparison of official statistics on child injury and safeguarding?

Preliminary work has also been undertaken on:

Interpretation of data

What official statistics tell us about incidence of preventable child death, injury, abuse and neglect in England and how do these figures compare with other developed countries? 
Figure 2.1, below provides a summary of the methods employed to meet the aims and objectives of the research.

\section{Figure 2.1: Summary of Method Used (comparison of international data on child protection)}

Search of websites of international organisations (e.g. UN,

WHO) for summary data on individual countries

\section{Selection of countries for further analysis}

Search of websites of selected countries (statistical offices,

child welfare agencies) and identification and listing of child

protection variables collected by country

Interviews with experts from selected countries regarding specific issues of data collection and comparability

Collection of published numerical data from each selected

country and comparisons made where appropriate

Table 2.1: International Organisations and Databases Used in the Initial

\section{Search}

\begin{tabular}{|l|l|}
\hline WHO & GHO Global Health Observatory \\
\hline ISPCAN & $\begin{array}{l}\text { International Society for Prevention of Child Abuse and } \\
\text { Neglect }\end{array}$ \\
\hline EUROSTAT & $\begin{array}{l}\text { European Commission for Prevention of Child Abuse and } \\
\text { Neglect }\end{array}$ \\
\hline UNICEF & \\
\hline ChildOnEurope & European Network for National Observatories on Childhood \\
\hline EUPHIX & European Union Public Health Information System \\
\hline OECD & Organisation for Economic Co-Operation and Development \\
\hline Eurosafe & EU Injury Database \\
\hline ENHIS & European Environment and Health Information System \\
\hline
\end{tabular}


Initially, the websites of international organisations (listed in Table 1) were searched to ascertain which variables relating to child mortality and welfare are collated by international organisations to assist in comparing similarities and differences between countries. This produced a list of around 200 potentially relevant variables which were classified under the following categories:

- Mortality/injury

- Risk factors/maltreatment

- Health/health care

- Demographics/social economic status.

An electronic database was constructed to store these data for analysis. Examination of these variables revealed that none related directly to prevalence of physical abuse, sexual abuse, emotional abuse and neglect in the developed world ${ }^{1}$. Eleven variables all relating to child mortality were identified; the most relevant to the study was child death due to negligence, maltreatment or physical assault (OECD,SF3.4 Family Violence database).

To identify seven countries for in-depth analysis the OECD countries were ranked, based on the amount of data they submitted for international publications on child mortality. The criteria below were therefore adopted to assist with country selection:

- Countries had provided data on mortality variables relating to child death due to negligence, maltreatment or physical assault for international comparison

- Countries in the developed world

- A wide geographical spread which includes Europe, America and Australia

\footnotetext{
${ }^{1}$ There were some variables that would assist in understanding the prevalence of intimate partner violence, parental mental ill-health and substance misuse which research demonstrates increase the risk of children suffering harm.
} 
Twelve countries were short-listed for inclusion in the in-depth phase of the study on this basis. These were Australia, Canada, Denmark, Finland, France, Netherlands, New Zealand, Norway, Sweden, USA, Italy and Belgium (in addition to England). Work was then undertaken to identify what child welfare data were collected and published nationally in each country. To maximise the likelihood that comparative analysis on key variables would be possible, consideration was given to which countries had:

- National datasets or publications including a range of child welfare variables

- Regular, systematic collection, collation and reporting of data on child welfare on a national basis

- Up to date information that was available and accessible

The following six countries, in addition to England, were selected for further scrutiny: Australia, Canada, Denmark, Finland, Norway and the USA. Numerical data were then extracted for each of the selected countries either from published online datasets or from annual reports. Links to sources of data that are used in the study are provided in Annex One. All data (and contextualising information from State Party reports) were stored in an electronic database to facilitate comparisons between countries.

To assist with understanding similarities and differences in child welfare systems and their implications, as well as variations in language and terminology on the comparability of data, telephone interviews were undertaken with key experts in each country. These explored: the type and quality of data collected, the rationale for its collection and challenges of within country and/or making crossnational comparisons. Information was also collected from each country's most recent State Party report to the UN Convention on the Rights of the Child ${ }^{2}$; these provide an overview of the systems and processes in place and developments in policy and practice.

\footnotetext{
${ }^{2}$ Except in the USA as they have not ratified the UN CRC
} 


\section{The Electronic Database}

During the study a database was constructed as a convenient means of storing detailed information concerning the child protection data held by each of the seven countries. However, it clearly has a wider application. At present, for each country, it holds comprehensive information concerning whether data are collected at key stages in the child protection process. However, it has been constructed in such a way as to provide links to population statistics and to hold numerical data in a number of categories including data on: referrals, assessments, services and plans, looked after children and mortality. It could be developed further as a means of further collating and comparing international data. 


\section{Chapter Three: Safeguarding processes and procedures and definitions of child abuse}

\section{Introduction}

It is widely recognised that official statistics underestimate the prevalence of maltreatment based on self-reports and community surveys (Gilbert et al., 2009). Factors contributing to this may include failures to recognise abuse and neglect, failures to report it or failures of agencies to either substantiate it or offer a service response. This Chapter highlights how variations in safeguarding policies and procedures in different countries may impact on the data that are collected to monitor activity to protect and promote the welfare of children and how similarities and differences in operational definitions of abuse and neglect, underpinned by legislation and statutory guidance, may influence decision-making and the comparability of data within and/or between countries.

\section{Safeguarding processes and procedures}

Each country and/or regional jurisdiction has legislation, policies and procedures which govern decision-making to protect and promote the welfare of children. Variations in these frameworks will influence both what data are collected and when. This will have a bearing on the comparability of the data. Annex Two provides an overview of safeguarding children procedures and processes from referral through to placement in out-of home care in the seven countries. It also outlines the data collection and monitoring systems in place and explores recent developments in policy and practice which may influence recognition and responses to suspected abuse. Broadly speaking, these reports reveal the following issues that may impact on both the type of data collected and how it should be interpreted.

Firstly, countries such as England and Norway, which have strong centralised systems, are more readily able to gather reliable national datasets than those such as Canada, Australia, and the USA, where there is greater diversity. In Canada, Australia and the USA, responsibility for safeguarding and protecting 
children from abuse or neglect is largely held at provincial or state level, with the result that there are disparities in legislative frameworks and administrative systems. Definitions may differ at local level (for instance, Canadian provinces differ over the age of majority) and these will impact on child protection data. Collating the data at a national level can also be problematic for practical reasons.

- In the USA, data collection is centralised through the National Child Abuse and Neglect Data System (NCANDS), which collates and holds longitudinal case level data on virtually all children who are reported to child protection services throughout the United States. While this is a comprehensive dataset, it is limited by the availability of consistent data items from each state and by variations between states in their operational definitions of maltreatment.

- In Australia each state or territory provides aggregate data to the Australian Institute of Health and Welfare, which collates and publishes annual statistics on child protection. Individual case level data are not currently held at a national level but consideration is being given to introducing this in the future (AIHW, 2010) ${ }^{3}$.

- In Canada, significant differences in the approach of each province and territory mean that national data collection and monitoring is particularly problematic. The solution has been to commission trained researchers to piece together relevant data from a wealth of child welfare agencies every five years. The Canadian Incidence Study of Reported Child Abuse is comprehensive, and may well provide more reliable data than that collected through administrative processes; however, the data may be up to five years old, and there is no guarantee that the quinquennial collections will continue to be funded.

\footnotetext{
${ }^{3}$ The method of collecting national child protection data is undergoing significant change. Currently the data are provided to the AlHW in aggregate form in Excel spreadsheets. All jurisdictions are committed to the development of a unit record data collection and it is seen as a major project under the National Framework for Protecting Australia's Children...Work continues with state and territories and the AlHW to progress the national child protection unit record collection (AlHW, 2010, p.7).
} 
Secondly, different approaches to safeguarding children will have a substantial impact on the manner in which maltreatment is identified and the services offered, and consequently on the numbers of children identified at each stage of the process. It is easy to confuse differences which have arisen through policy and legislative frameworks with genuine differences in the prevalence of abuse and the effectiveness of services. Gilbert and colleagues (2009) distinguish between a child and family welfare approach and a child safety approach. A child and family welfare approach operates in most Western European countries, including England, Norway, Denmark and Finland. This is essentially a needs based approach, in which child protection investigations are seen as part of a continuum of services for children in need and their families, and agencies respond to allegations of maltreatment alongside referrals for family support services for children who may be in need but not likely to suffer significant harm. This model lends itself to an ecological approach to assessment, and provides a rationale for early interventions, and the strengthening of primary and secondary level services.

A child safety approach operates in the USA, Canada and some Australian states. In this model child protection investigations are seen as distinct from the provision of child welfare services, which are likely to be offered by different, possibly voluntary agencies. In this approach, the focus is on risk, rather than need, services are aimed at preventing the recurrence of maltreatment, rather than on the wider needs of the child and family, and there is an increased use of actuarial risk assessment to predict the risk of future harm. This model has a narrower focus and is therefore likely to provide more comparable data. However, this will also be influenced by similarities and differences in how abuse is defined and the threshold at which children are deemed to be at sufficient risk for statutory intervention to be warranted. This is explored below.

\section{Defining child abuse}

It is well recognised that common operational definitions for different forms of abuse at the international level facilitate cross-national comparisons, and that differences may compromise their validity (ChildONEurope, 2009). Different definitions will result both in different rates of identification and response and also 
in differences in the relative numbers or percentages of children classified as suffering each type of abuse. For instance, in some countries, physical punishment of children is banned, whilst in others it is considered acceptable, at least to a certain degree: this could impact on both the rate per thousand of children identified as being abused and also the extent of physical abuse as compared with other types of maltreatment. This chapter explores similarities and differences in the operational definitions employed to classify sexual abuse, physical abuse, neglect, emotional or psychological abuse and intimate partner violence to inform the data collection process and their implications.

\section{Availability}

Data on the type of maltreatment that children known to child welfare or child protection services have experienced are collected in every sample country except Finland and Denmark. It has proved possible to identify how these types are defined in the three English speaking countries, but not in Norway, where the data are collected but it has not proved possible to locate a precise definition.

The definitions vary in their precision. Those used in Canada are more comprehensive and detailed than those employed by the other countries. This reflects the manner in which the data are collected. The Canadian data are collected by specially trained researchers in each of the provinces; the detailed definition reflects the extensive efforts given to ensuring inter-rater reliability ${ }^{4}$. Other countries rely on administrative data collected by practitioners and sometimes administrative staff in the course of their every day work. The data from these countries are more likely to reflect personal perspectives than in Canada, where data collection is more carefully monitored. Australian definitions are generally short and lacking in detail: this could lead to under-reporting and to less rigorous classification than in other countries.

\footnotetext{
${ }^{4}$ Interview with Nico Trocme, Canada
} 


\section{Comparability of definitions}

\section{Sexual abuse}

Table 3.1 below provides an overview of how sexual abuse is defined by international agencies and at a national level within three countries in the study sample.

\section{Table 3.1: Definitions of sexual abuse}

\begin{tabular}{|c|c|}
\hline International & $\begin{array}{l}\text { The involvement of a child in sexual activity that he or she does not fully } \\
\text { comprehend and is unable to give informed consent to, or for which the child is } \\
\text { not developmentally prepared, or else that violates the laws or social taboos of } \\
\text { society. Children can be sexually abused both by adults and other children who } \\
\text { are - by virtue of their age or stage of development - in a position of } \\
\text { responsibility, trust or power over the victim (WHO and ISPCAN Guide, 2006). }\end{array}$ \\
\hline Australia & $\begin{array}{l}\text { Any act by a person having the care of the child which exposes a child to, or } \\
\text { involves a child in, sexual processes beyond his or her understanding or } \\
\text { contrary to accepted community standards (AlHW, 2010). }\end{array}$ \\
\hline Canada & $\begin{array}{l}\text { Categories of sexual abuse defined in the CIS-2008 include; sexual } \\
\text { molestation or sexual exploitation. This includes oral, vaginal or anal sexual } \\
\text { activity; attempted sexual activity; sexual touching or fondling; exposure; } \\
\text { voyeurism; involvement in prostitution or pornography; and verbal sexual } \\
\text { harassment. If several forms of sexual activity are involved the most intrusive } \\
\text { form was indentified. Intra-familial and extra-familial sexual abuse, as well as } \\
\text { sexual abuse involving an older child or youth perpetrator were included. } \\
\text { Separate categories of sexual abuse were: } \\
\text { - Penetration: Penile, digital or object penetration of vagina or anus. } \\
\text { - Attempted penetration: Attempted penile, digital, or object penetration of } \\
\text { vagina or anus. } \\
\text { - Oral sex: Oral contact with genitals either by perpetrator or by the child. } \\
\text { - Fondling: Touching or fondling genitals for sexual purposes. } \\
\text { - Sex talk or images: Verbal or written proposition, encouragement or } \\
\text { suggestion of a sexual nature (include face to face, phone, written and } \\
\text { Internet contact, as well as exposing the child to pornographic material). } \\
\text { - Voyeurism: Include activities where the alleged perpetrator observes the } \\
\text { child for the perpetrator's sexual gratification. Use the "Exploitation" code if } \\
\text { voyeurism includes pornographic activities. } \\
\text { • Exhibitionism: Include activities where the perpetrator is alleged to have } \\
\text { exhibited himself or herself for his or her own sexual gratification. }\end{array}$ \\
\hline
\end{tabular}




\begin{tabular}{|l|l|}
\hline \multirow{5}{*}{ England } & $\begin{array}{l}\text { • Exploitation: Include situations where an adult sexually exploits a child for } \\
\text { purposes of financial gain or other profit, including pornography and } \\
\text { prostitution. } \\
\text { • Other sexual abuse: Other or unspecified sexual abuse (Public Health } \\
\text { Agency of Canada, 2010). }\end{array}$ \\
\hline Denmark & $\begin{array}{l}\text { Sexual abuse involves forcing or enticing a child or young person to take part } \\
\text { in sexual activities, not necessarily involving a high level of violence, whether } \\
\text { or not the child is aware of what is happening. The activities may involve } \\
\text { physical contact, including assault by penetration (for example, rape or oral } \\
\text { sex) or non-penetrative acts such as masturbation, kissing, rubbing and } \\
\text { touching outside of clothing. They may also include non-contact activities, such } \\
\text { as involving children in looking at, or in the production of, sexual images, } \\
\text { watching sexual activities, encouraging children to behave in sexually } \\
\text { inappropriate ways, or grooming a child in preparation for abuse (including via } \\
\text { the internet). Sexual abuse is not solely perpetrated by adult males. Women } \\
\text { can also commit acts of sexual abuse, as can other children (HM Government, } \\
\text { 2010). }\end{array}$ \\
\hline No child abuse data items currently collected
\end{tabular}

As the Table illustrates, there is considerable consistency between countries concerning what behaviour is perceived to constitute sexual abuse.

Common features of definitions reflect that such acts are:

- Beyond a child's understanding or development

- Contrary to accepted societal norms or standards

- For the gratification of the perpetrator

- Forced - although not necessarily by violence 
Most countries specify that perpetrators can be other children and young people as well as adults. However, this is not made explicit in the Australian or North American definitions. Conversely, the English version makes it clear that perpetrators can be women and other children, in order to promote better recognition.

The American definition is the only one to specifically include the risk of sexual abuse, a factor that may increase recognition and reporting.

\section{Physical abuse}

\section{Table 3.2: Definitions of physical abuse}

\begin{tabular}{|c|c|}
\hline International & $\begin{array}{l}\text { Physical abuse of a child is defined as the intentional use of physical force against } \\
\text { a child that results in - or has a high likelihood of resulting in - harm for the child's } \\
\text { health, survival, development or dignity. This includes hitting, beating, kicking, } \\
\text { shaking, biting, strangling, scalding, burning, poisoning and suffocating (WHO and } \\
\text { ISPCAN Guide, 2006). }\end{array}$ \\
\hline Australia & $\begin{array}{l}\text { Any non-accidental physical act inflicted upon a child by a person having the care } \\
\text { of a child (AlHW, 2010). }\end{array}$ \\
\hline Canada & $\begin{array}{l}\text { Categories of physical abuse defined in the CIS - } 2008 \text { include; whether a child } \\
\text { was physically harmed or could have suffered physical harm as a result of the } \\
\text { behaviour of the person looking after the child, this can involve any alleged } \\
\text { physical assault, including abusive incidents involving some form of punishment. } \\
\text { Types of physical abuse are: } \\
\text { - Shake, push, grab or throw: Includes pulling or dragging a child as well as } \\
\text { shaking an infant. } \\
\text { - Hit with hand: Including slapping and spanking, but not punching. } \\
\text { - Punch, kick or bite: Includes as well any other hitting with other parts of the } \\
\text { body e.g., elbow or head. } \\
\text { - Hit with object: Includes hitting with a stick, a belt or other object, throwing an } \\
\text { object at a child, but does not include stabbing with a knife. } \\
\text { - Choking, poisoning or stabbing: Includes any other form of physical abuse, } \\
\text { including choking, strangling, stabbing, burning, shooting, poisoning and the } \\
\text { abusive use of restraints. } \\
\text { - Other physical abuse: Other or unspecified physical abuse (Public Health } \\
\text { Agency of Canada, 2010). }\end{array}$ \\
\hline Denmark & No child abuse data items currently collected \\
\hline England & Physical abuse may involve hitting, shaking, throwing, poisoning, burning or \\
\hline
\end{tabular}




\begin{tabular}{|l|l|}
\hline & $\begin{array}{l}\text { scalding, drowning, suffocating, or otherwise causing physical harm to a child. } \\
\text { Physical harm may also be caused when a parent or carer fabricates the } \\
\text { symptoms of, or deliberately induces, illness in a child (HM Government, 2010). }\end{array}$ \\
\hline Finland & No child abuse data items currently collected \\
\hline Norway & $\begin{array}{l}\text { It has not proved possible to identify a precise definition of physical abuse, } \\
\text { although data are collected on this issue. Section } 30 \text { of the Norwegian Children Act } \\
1982 \text { (updated, 1987) states: 'The child must not be exposed to violence, or in any } \\
\text { other way be treated so as to harm or endanger his or her mental or physical } \\
\text { health'. This includes corporal punishment by parents in the home. (Sandbaek, } \\
\text { Bakketeig and Einarsson, 2008) }\end{array}$ \\
\hline USA & $\begin{array}{l}\text { A type of maltreatment that refers to physical acts that caused or could have } \\
\text { caused physical injury to a child. For example bruising. This can include risk of } \\
\text { physical abuse or threatened harm (U.S Department of Health and Human } \\
\text { Services, 2010). }\end{array}$ \\
\hline
\end{tabular}

There is an overall consensus concerning features of physical abuse. Alongside descriptive accounts of incidents the following features are identified:

- Intentional or non-accidental use of force causing physical harm

- Physical abuse inflicted on a child by an adult caring for the child

However, domestic corporal punishment is unlawful, and therefore regarded as physical abuse in 29 countries including Norway, Finland and Denmark. It is still lawful, although controversial in Canada, Australia, England and the USA. These differences may impact on the prevalence of physical abuse and also on the thresholds for identification.

In the English speaking countries, spanking or smacking children is legal. Corporal punishment which causes physical harm is generally regarded as 'unreasonable' and therefore unlawful. The Canadian definition of physical abuse acknowledges that physical abuse can involve a form of punishment.

The English definition of physical abuse explicitly identifies a parent or carer fabricating the symptoms of illness or deliberately causes illness in their definition of what constitutes abuse. In the USA attention is also drawn to the risk of 
physical abuse or threatened harm. Both these factors may increase recognition in these countries.

\section{Neglect and emotional abuse}

In contrast to the general consensus between countries with regards to sexual and physically abusive acts there is less agreement surrounding neglect and emotional abuse. In part this is because there is overlap between the two phenomena (Ward et al., 2004).

Table 3.3 provides an overview of the definitions of neglect employed by each country, WHO and ISPCAN

\section{Table 3.3: Definitions of neglect}

\begin{tabular}{|l|l|}
\hline International & $\begin{array}{l}\text { Neglect includes both isolated incidents, as well as a pattern of failure over time on } \\
\text { the part of a parent or other family member to provide for the development and } \\
\text { well-being of the child - where the parent is in a position to do so - in one or more } \\
\text { of the following areas: health, education, emotional development, nutrition, shelter } \\
\text { and safe living conditions (WHO and ISPCAN Guide, 2006). }\end{array}$ \\
\hline Australia & $\begin{array}{l}\text { Any serious omissions or commissions by a person having the care of a child } \\
\text { which, within the bounds of cultural tradition, constitute a failure to provide } \\
\text { conditions which are essential for the healthy, physical and emotional development } \\
\text { of a child (AlHW, 2010). }\end{array}$ \\
\hline $\begin{array}{l}\text { Canada the child has suffered harm or the child's safety or development has been } \\
\text { endangered as a result of a failure to provide for or protect the child. Note that the } \\
\text { term "neglect" is not consistently used in all provincial/territorial statutes, but } \\
\text { interchangeable concepts include "failure to care and provide for or supervise and } \\
\text { protect," "does not provide," "refuses or is unavailable or unable to consent to } \\
\text { treatment." Categories of neglect include: } \\
\text { - Failure to supervise: Physical harm: The child suffered physical harm or is at } \\
\text { risk of suffering physical harm because of the caregiver's failure to supervise } \\
\text { or protect the child adequately. Failure to supervise includes situations where a } \\
\text { child is harmed or endangered as a result of a caregiver's actions (e.g., drunk } \\
\text { driving with a child, or engaging in dangerous criminal activities with a child). } \\
\text { Failure to supervise: Sexual abuse: The child has been or is at substantial risk } \\
\text { of being sexually molested or sexually exploited, and the caregiver knows or } \\
\text { should have known of the possibility of sexual molestation and failed to protect } \\
\text { the child adequately. } \\
\text { Permitting criminal behaviour: A child has committed a criminal offence (e.g., }\end{array}$ \\
\hline
\end{tabular}




\begin{tabular}{|c|c|}
\hline & $\begin{array}{l}\text { theft, vandalism, or assault) because of the caregiver's failure or inability to } \\
\text { supervise the child adequately. } \\
\text { Physical neglect: The child has suffered or is at substantial risk of suffering } \\
\text { physical harm caused by the caregiver(s)' failure to care and provide for the } \\
\text { child adequately. This includes inadequate nutrition/clothing, and unhygienic, } \\
\text { dangerous living conditions. There must be evidence or suspicion that the } \\
\text { caregiver is at least partially responsible for the situation. } \\
\text { Medical neglect (includes dental): The child requires medical treatment to cure, } \\
\text { prevent, or alleviate physical harm or suffering and the child's caregiver does } \\
\text { not provide, or refuses, or is unavailable, or unable to consent to the treatment. } \\
\text { This includes dental services when funding is available. } \\
\text { Failure to provide psych. treatment: The child is suffering from either emotional } \\
\text { harm demonstrated by severe anxiety, depression, withdrawal, or self- } \\
\text { destructive or aggressive behaviour, or a mental, emotional or developmental } \\
\text { condition that could seriously impair the child's development. The child's } \\
\text { caregiver does not provide, or refuses, or is unavailable, or unable to consent } \\
\text { to treatment to remedy or alleviate the harm. This category includes failing to } \\
\text { provide treatment for school-related problems such as learning and behaviour } \\
\text { problems, as well as treatment for infant development problems such as non- } \\
\text { organic failure to thrive. A parent awaiting service should not be included in } \\
\text { this category. } \\
\text { Abandonment: The child's parent has died or is unable to exercise custodial } \\
\text { rights and has not made adequate provisions for care and custody, or the child } \\
\text { is in a placement and parent refuses/is unable to take custody. } \\
\text { child is experiencing mental, emotional or developmental problems associated } \\
\text { with school, and treatment is offered but caregivers do not cooperate with } \\
\text { treatment, classify the case under failure to provide treatment as well (Public } \\
\text { Health Agency of Canada, } 2010 \text { ). }\end{array}$ \\
\hline Denmark & No child abuse data items currently collected \\
\hline England & $\begin{array}{l}\text { Neglect is the persistent failure to meet a child's basic physical and/or } \\
\text { psychological needs, likely to result in the serious impairment of the child's health } \\
\text { or development. } \\
\text { Neglect may occur during pregnancy as a result of maternal substance abuse. } \\
\text { Once a child is born, neglect may involve a parent or carer failing to: } \\
\text { - Provide adequate food, clothing and shelter (including exclusion from } \\
\text { home or abandonment) } \\
\text { - Protect a child from physical and emotional harm or danger }\end{array}$ \\
\hline
\end{tabular}




\begin{tabular}{|l|l|}
\hline \multirow{2}{*}{$\begin{array}{l}\bullet \quad \text { Ensure adequate supervision (including the use of inadequate care-givers) } \\
\text { It may also include neglect of, or unresponsiveness to, a child's basic emotional } \\
\text { needs (HM Government, 2010). }\end{array}$} \\
\hline Finland & $\begin{array}{l}\text { No child abuse data items currently collected } \\
\text { It is evident from the statistical data that this includes parents' drug excess, inability } \\
\text { to care and domestic conditions. However, it has not proved possible to find a full } \\
\text { definition. }\end{array}$ \\
\hline USA & $\begin{array}{l}\text { Medical neglect: A type of maltreatment caused by failure by the caregiver } \\
\text { to provide for the appropriate health care of the child although financially } \\
\text { able to do so, or offered financial or other means to do so. }\end{array}$ \\
$\begin{array}{l}\text { Neglect or deprivation of necessities: A type of maltreatment that refers to } \\
\text { the failure by the caregiver to provide needed, age-appropriate care } \\
\text { although financially able to do so or offered financial or other means to do } \\
\text { so. This can include foetal alcohol syndrome, prenatal substance abuse } \\
\text { exposure, abandonment or educational neglect (U.S Department of Health } \\
\text { and Human Services, 2010). }\end{array}$
\end{tabular}

At least 13 characteristics are covered by these definitions overall. These include:

- Failure by a parent or carer to provide for the development and wellbeing of a child/inability to care (cited by WHO and ISPCAN, Australia, Canada, England and Norway)

- Failure to adequately supervise a child leading to potential risk of harm (cited by England and Canada).

- Physical neglect/domestic conditions (England, Canada, USA and Norway)

- Medical neglect (Canada, England and USA)

- Educational neglect (Canada and USA)

- Abandonment (Canada, England and USA)

- Exposure to in utero alcohol/drugs (USA, England)

- Parents' drug excess (Norway)

- Unresponsiveness to child's basic emotional needs (England) 


\section{Emotional abuse}

There are also variations between countries in definitions of emotional/psychological abuse. The complex and multifaceted nature of emotional abuse means that a broad range of operational definitions have been utilised for research purposes and there is limited consensus concerning how it should be assessed (Iwaniec, 1995). Nevertheless, common elements in the conceptualisation of emotional abuse are that it is a) longstanding, repetitive and sustained and $b$ ) relates to a relationship between a caretaker and child, rather than a single event. Table 3.4 below provides an overview of the definitions employed in different countries.

\section{Table 3.4: Definitions of emotional/psychological abuse}

\begin{tabular}{|c|c|}
\hline International & $\begin{array}{l}\text { Emotional and psychological abuse involves both the isolated incidents, as well as } \\
\text { a pattern of failure over time on the part of a parent or caregiver to provide a } \\
\text { developmentally appropriate and supportive environment...Abuse of this type } \\
\text { includes: the restriction of movement; pattern of belittling, blaming, threatening, } \\
\text { frightening, discriminating against or ridiculing; and other non-physical forms of } \\
\text { rejection or hostile treatment (WHO and ISPCAN Guide, 2006). }\end{array}$ \\
\hline Australia & $\begin{array}{l}\text { Any act by a person having the care of a child that results in the child suffering any } \\
\text { kind of significant emotional deprivation or trauma (AIHW, 2010) }\end{array}$ \\
\hline Canada & $\begin{array}{l}\text { If the child has suffered, or is at substantial risk of suffering, emotional harm at the } \\
\text { hands of the person looking after the child. Categories include: } \\
\text { - Terrorizing or threat of violence: A climate of fear, placing the child in } \\
\text { unpredictable or chaotic circumstances, bullying or frightening a child, threats of } \\
\text { violence against the child or child's loved ones or objects. } \\
\text { - Verbal abuse or belittling: Non-physical forms of overtly hostile or rejecting } \\
\text { treatment. Shaming or ridiculing the child, or belittling and degrading the child. } \\
\text { - Isolation/confinement: Adult cuts the child off from normal social experiences, } \\
\text { prevents friendships or makes the child believe that he or she is alone in the } \\
\text { world. Includes locking a child in a room, or isolating the child from the normal } \\
\text { household routines. } \\
\text { - Inadequate nurturing or affection: Through acts of omission, does not provide } \\
\text { adequate nurturing or affection. Being detached, uninvolved; failing to express } \\
\text { affection, caring and love, and interacting only when absolutely necessary. } \\
\text { - Exploiting or corrupting behaviour: The adult permits or encourages the child to } \\
\text { engage in destructive, criminal, antisocial, or deviant behaviour (CIS-2008) } \\
\text { (Public Health Agency of Canada, 2010). }\end{array}$ \\
\hline
\end{tabular}




\begin{tabular}{|l|l|}
\hline Denmark & No child abuse data items currently collected \\
\hline England & $\begin{array}{l}\text { Emotional abuse is the persistent emotional maltreatment of a child such as to } \\
\text { cause severe and persistent adverse effects on the child's emotional development. } \\
\text { It may involve conveying to children that they are worthless or unloved, } \\
\text { inadequate, or valued only insofar as they meet the needs of another person. It } \\
\text { may include not giving the child opportunities to express their views, deliberately } \\
\text { silencing them or 'making fun' of what they say or how they communicate. It may } \\
\text { feature age or developmentally inappropriate expectations being imposed on } \\
\text { children. These may include interactions that are beyond the child's developmental } \\
\text { capability, as well as overprotection and limitation of exploration and learning, or } \\
\text { preventing the child participating in normal social interaction. It may involve seeing } \\
\text { or hearing the ill-treatment of another. It may involve serious bullying (including } \\
\text { cyber-bullying), causing children frequently to feel frightened or in danger, or the } \\
\text { exploitation or corruption of children. Some level of emotional abuse is involved in } \\
\text { all types of maltreatment of a child, though it may occur alone (HM Government, } \\
\text { 2010). } \\
\text { No child abuse data items currently collected }\end{array}$ \\
\hline Finland & $\begin{array}{l}\text { It has not proved possible to identify a definition of emotional abuse in Norway, } \\
\text { although statistical data are collected }\end{array}$ \\
\hline Norway & $\begin{array}{l}\text { A type of maltreatment that refers to acts or omissions, other than physical abuse } \\
\text { or sexual abuse that caused, or could have caused, conduct, cognitive, affective, } \\
\text { or other mental disorders and includes emotional neglect, psychological abuse, } \\
\text { and mental injury. Frequently occurs as verbal abuse or excessive demands on a } \\
\text { child's performance. This can include risk of physical or sexual abuse, threatened } \\
\text { harm, or domestic violence (U.S Department of Health and Human Services, } \\
\text { 2010). }\end{array}$ \\
\hline USA &
\end{tabular}

The following are highlighted within definitions:

- Developmentally inappropriate expectations and an unsupportive environment for children (WHO and ISPCAN and England)

- Restriction of a child's movement and social isolation (WHO and ISPCAN, Canada and England)

- Belittling, blaming, threatening or degrading a child (WHO and ISPCAN, Canada, England and USA)

- Frightening a child (WHO and ISPCAN, Canada and England)

- Causing emotional harm or trauma (Australia, Canada, England and USA)

- Inadequate nurturing and affection (Canada) 
- Exploitation or corruption of a child (Canada and England)

- Seeing or hearing ill-treatment of another/domestic violence/threats of violence against a child's loved ones (England, USA, Canada)

- Risk of other types of abuse, experiencing other types of abuse (USA and England)

\section{Witnessing violence}

As indicated above, England, the USA and Canada all include domestic violence within their definitions of emotional abuse. However, the USA, Canada and Norway also have a separate data item on witnessing violence as a type of abuse. Definitions are available from the USA and Canada, where there is much consensus about this type of abuse. Both countries recognise that violence can be both physical and emotional and can be directly witnessed by a child or indirectly witnessed, for example within the home environment. Each refers to inter-spousal or intimate partner violence, however, Canada extends the category further to include acts of violence between a child's carer and another person who is not their partner, for example a neighbour, aunt, uncle or grandparent.

\section{Table 3.5: Definitions of witnessing violence}

\begin{tabular}{|l|l|}
\hline International & Missing data \\
\hline Australia & Not defined as a separate variable \\
\hline Canada & $\begin{array}{l}\text { - Direct witness to physical violence: The child is physically present and } \\
\text { - Indirect exposure to physical violence: Includes situations where the child } \\
\text { overhears but does not see the violence between intimate partners; or sees } \\
\text { some of the immediate consequences of the assault (e.g. injuries to the mother); } \\
\text { or the child is told or overhears conversations about the assault. } \\
\text { • Exposure to emotional violence: Includes situations in which the child is } \\
\text { exposed directly or indirectly to emotional violence between intimate partners. } \\
\text { Includes witnessing or overhearing emotional abuse of one partner by the other. } \\
\text { • Exposure to non-partner physical violence: A child has been exposed to } \\
\text { violence occurring between a caregiver and another person who is not the } \\
\text { spouse/partner of the caregiver (e.g. between a caregiver and a neighbour, } \\
\text { grandparent, aunt or uncle) (Public Health Agency of Canada, 2010). }\end{array}$ \\
\hline Denmark & $\begin{array}{l}\text { No data collected } \\
\text { Not defined as a separate variable (but impairment suffered from seeing or hearing }\end{array}$ \\
\hline
\end{tabular}




\begin{tabular}{|l|l|}
\hline & $\begin{array}{l}\text { the ill-treatment of another is included in the English definition of significant harm } \\
\text { and would be recorded as emotional abuse (see above). }\end{array}$ \\
\hline Finland & No data collected \\
\hline Norway & Defined as a separate variable - cannot find description/definition \\
\hline USA & $\begin{array}{l}\text { Incidents of inter-spousal physical or emotional abuse perpetrated by one of the } \\
\text { spouses or parent figures upon the other spouse or parent figure in the child's } \\
\text { home environment (U.S Department of Health and Human Services, 2010). }\end{array}$ \\
\hline
\end{tabular}

As is evident from the above, there is less consensus regarding definitions of neglect, emotional abuse and witnessing domestic violence in the sample countries. For instance:

- The Australian definitions are less specific than those that apply elsewhere. This will cause particular difficulties in making cross-national comparisons in this area, where definitions are already relatively fluid.

- The American definition of neglect does not specifically include supervisory neglect - a major issue amongst adolescents (see Rees et al., forthcoming)

- The English definition of neglect does not specifically refer to educational neglect

- Exposure in utero to alcohol/drugs is not included in the Canadian definition of neglect

- Unresponsiveness to a child's emotional needs is cited in England's definition of neglect and Canada's definition of emotional abuse (inadequate nurturing or affection)

- The threat of sexual or physical abuse is included in the definitions of physical, sexual and also emotional abuse in the USA. In England and Canada it is only included in the definition of emotional abuse.

- Witnessing domestic violence is a separate category of abuse in the USA, Canada and Norway, but not England and Australia.

- Norway is the only country in the sample to cite parental substance misuse within its definition of neglect. This is likely to have a substantial impact on the numbers of children included. 
The ChildONEurope Review on National Systems and Statistics and Registration on Child Abuse (2007) revealed that there was general agreement within all European countries surveyed $(n=27)$ that sexually abusive behaviour and physical abuse were forms of maltreatment. It also found that there was less consensus around neglect, abandonment, emotional abuse and witnessing intimate partner violence (although the majority of respondents did still identify these events as abusive). This point seems to be reflected in the disparities within the definitions discussed above. In order to make sensible cross national comparisons, one would either need to collapse these three categories into one larger group that included them all, or focus on the more easily defined types of sexual and physical abuse, over which there is more consensus. Available data were extracted for sample countries and are presented below.

\section{Number and proportion of cases by abuse type shown in national statistics}

Table 3.6 below provides data on the number and proportion of cases by abuse type.

Table 3.6: Number and proportion of cases by abuse type ${ }^{5}$

\begin{tabular}{|l|l|l|l|l|l|l|l|l|l|l|}
\hline & \multicolumn{2}{|l|}{ Australia } & \multicolumn{2}{l|}{ Canada } & \multicolumn{2}{l|}{ England } & \multicolumn{2}{l|}{ Norway } & \multicolumn{2}{l|}{ USA } \\
\hline $\begin{array}{l}\text { Sexual } \\
\text { abuse }\end{array}$ & 5591 & $10.2 \%$ & 2607 & $3.1 \%$ & 2046 & $6.0 \%$ & 77 & $0.8 \%$ & 69184 & $7.9 \%$ \\
\hline $\begin{array}{l}\text { Physical } \\
\text { abuse }\end{array}$ & 11789 & $21.6 \%$ & 17212 & $20.1 \%$ & 4433 & $13.0 \%$ & 307 & $3.2 \%$ & 122350 & $14.0 \%$ \\
\hline Neglect $^{6}$ & 15579 & $28.5 \%$ & 28939 & $33.9 \%$ & 15686 & $46.0 \%$ & 8568 & $88 \%$ & 556105 & $63.6 \%$ \\
\hline $\begin{array}{l}\text { Emotional } \\
\text { abuse }\end{array}$ & 21662 & $39.7 \%$ & 36682 & $42.9 \%$ & 9207 & $27.0 \%$ & 783 & $8.0 \%$ & 55196 & $6.3 \%$ \\
\hline $\begin{array}{l}\text { Other, } \\
\text { unknown } \\
\text { or missing }\end{array}$ & 0 & $0 \%$ & 0 & $0 \%$ & 2728 & $8.0 \%$ & 0 & $0 \%$ & 71044 & $8.1 \%$ \\
\hline Total & 85440 & $100 \%$ & 85440 & $100 \%$ & 34100 & $100 \%$ & 9735 & 100 & 873879 & $100 \%$ \\
\hline
\end{tabular}

\footnotetext{
${ }^{5}$ The figures cited draw on the latest available data for each country at $30^{\text {th }}$ October 2010 . Further details are provided in Annex One.

${ }^{6}$ Includes medical neglect (data collected in the USA) and parent's drug excess, inability to care and domestic conditions (data collected in Norway)

${ }^{7}$ Including intimate partner violence
} 
As is evident from the table, in all the sample countries for which data are available, the majority of maltreated children are either classified under the category of neglect (England, Norway and America) or emotional abuse (including domestic violence) (Australia and Canada). As outlined above, there is greatest definitional ambiguity at an international level concerning definitions of these two types of abuse and the boundaries between them are blurred. Taken together those children who fall into these two categories represent between 68.2 per cent (Australia) and 96 per cent (Norway) of all those who are identified as maltreated. If international comparisons were to focus on physical and sexual abuse, they would only include between 4\% (Norway) and 32\% (Australia) of maltreated children in these countries. Nevertheless, much could be learned from exploring the disparities between these figures.

The data shown in Table 3.6 are, however, collected at different points in the child protection process in different countries. In Australia, Canada and the USA, data on type of abuse is collected following assessment or investigation. Data in England and Norway are collected later; when a child becomes the subject of a child protection plan or is in receipt of 'assistance in the home'. The stage in the process at which the data are collected may distort the proportions of children in each category and this should be considered when undertaking cross-national comparisons. These issues are explored further in the next chapter. 


\section{Chapter Four: Availability and comparability of data on safeguarding children}

\section{Introduction}

A complex interplay of factors will influence public and professional decisions about whether or not to refer concerns that a child may be suffering, or likely to suffer, significant harm to children's social care. Post referral legislation and statutory guidance (among other things) will inform and influence the subsequent actions taken to safeguard children from harm. Countries collect data to assist them in examining levels of need and service responses intended to protect and promote the welfare of children and their families. This Chapter focuses upon what statistical data are collected, aggregated and published at a national level to help countries better understand recognition and responses to abuse and neglect. It is important to highlight that additional child-level and aggregate data are often collected by local authorities to monitor activity and to inform the decision-making process but exploration of this is beyond the scope of the study.

Broadly speaking, countries will collect a range of variables to assist with understanding the volume of cases coming to the attention of children's services and the:

- Characteristics of the children

- Characteristics and circumstances of perpetrator(s)

- Type(s) of abuse alleged and/or substantiated

- Service responses and interventions

Table 4.1 below provides details on the attribute data collected in each country. As this shows, every country collects data on children's gender and age, although the point at which these data were collected varied ${ }^{8}$. There was also a lack of consistency in the age bandings each country adopted.

\footnotetext{
${ }^{8}$ Only the USA and Canada collect data on the nature of children's disabilities (at the point of investigation), although definitions and classifications differ
} 
Table 4.1: Availability of attribute data

\begin{tabular}{|c|c|c|c|c|c|c|c|c|c|c|c|c|}
\hline \multirow[t]{2}{*}{ Country } & \multicolumn{3}{|l|}{ Referral } & \multicolumn{3}{|c|}{ Assessment } & \multicolumn{3}{|c|}{ Community based services } & \multicolumn{3}{|c|}{ Out-of-home care } \\
\hline & Gender & Age & Ethnicity & Gender & Age & Ethnicity & Gender & Age & Ethnicity & Gender & Age & Ethnicity \\
\hline Australia & Yes & Yes & Yes & Yes & Yes & Yes & No & Yes & No & Yes & Yes & Yes \\
\hline Canada & No & No & No & Yes & Yes & Yes & No & No & No & No & No & No \\
\hline Denmark & No & No & No & No & No & No & Yes & Yes & No & Yes & Yes & No \\
\hline England $^{9}$ & No & No & No & No & No & No & Yes & Yes & Yes & Yes & Yes & Yes \\
\hline Finland & No & Yes & No & No & No & No & No & Yes & No & Yes & Yes & No \\
\hline Norway & No & No & No & Yes & Yes & Yes & Yes & Yes & No & Yes & Yes & Yes \\
\hline USA & No & No & No & Yes & Yes & Yes & No & No & No & No & No & No \\
\hline
\end{tabular}

Every country except Denmark and Finland also collect ethnicity data, although the number of categories employed was more detailed in England than elsewhere. This presents opportunities to explore similarities and differences in the profile of children in receipt of services in different countries. In general, data on the characteristics and circumstances of alleged perpetrators of abuse were much more limited than that on the child. However, data on factors affecting parenting capacity, including substance misuse and mental ill-health, if collected more widely, could assist in understanding the influence of such factors on case progression.

Every country except Finland and Denmark collected data on the type of abuse children had been identified as suffering, or at risk of suffering. Pösö (personal communication) suggested that the value of collecting such data is not widely acknowledged by the public or politicians in either of these countries. As discussed in the previous chapter, the remaining countries supply data on physical abuse, neglect, emotional abuse and sexual abuse, although the operational definitions employed vary.

Data collection and analysis also revealed variations in the quantity of data collected at different points in the safeguarding processes. Denmark does not publish statistical data on children until they are in receipt of services. Even at this stage and beyond (when children enter out-of-home care) they collect minimal data. In contrast in Canada and the USA, for example, more data are

\footnotetext{
${ }^{9}$ The CIN Census 2010 was published shortly after this report was submitted. This statistical return does include data on gender, age and ethnicity for referrals and assessments.
} 
collected early in the child protection process. Relative to other countries in the study England collects a similar level of data at the point of referral and assessment and more than others in respect of looked after children. The availability and comparability of data at key stages in the child protection process is explored further below.

\section{Referrals and notifications}

Data on referrals and notifications provide an indication of the volume of cases entering child welfare or child protection systems. Reports requesting services or raising concerns that a child may be suffering, or is likely to suffer, significant harm may be made by a range of professionals, the public, a family member or the child themselves. The volume of referrals received by children's social care will depend upon a variety of factors including: professional and public knowledge and understanding of thresholds for statutory intervention; whether mandatory reporting laws are in place; legislation and policies governing recognition and response to maltreatment (child and family welfare approach or child-safety approaches ${ }^{10}$ ); media reporting and cultural attitudes including confidence in the child protection system; economic climate; levels of need (Gilbert et al., 2009; Holmes, Munro and Soper, 2010).

\section{Availability of data}

Table 4.2 below provides an overview of the key variables that countries collect on referrals. Data items that are only collected in one country have been excluded.

\footnotetext{
${ }^{10}$ These are broad approaches. New Zealand, the UK and most Western European counties are classified as operating child and family welfare models whereas the USA, some Australian states and Canada operate child safety models (Gilbert et al., 2009, p. 174)
} 
Table 4.2: Referral/notification data items collected

\begin{tabular}{|l|l|l|l|l|l|l|l|}
\hline Data item & Aus & Can & Den & Eng & Fin & Nor & USA \\
\hline Total referrals/notifications received & Yes $^{\star}$ & No & No & Yes & Yes & No & Yes \\
\hline By area/region/municipality/state & Yes & No & No & Yes & Yes & No & Yes \\
\hline Source of referral & Yes & Yes & No & No** & No & Yes & Yes \\
\hline Outcome & Yes & No & No & Yes & No & No & Yes \\
\hline
\end{tabular}

${ }^{*}$ For some states/territories in Australia **Data are not available from the DFE national statistical returns although local authorities do routinely collect these data. The ADCS (2010) have recently collated data on this and this is used in analysis.

Australia, England, Finland and the USA collect and publish statistical data on:

- Total number of referrals/notifications received (including a breakdown by region)

Australia, Canada ${ }^{11}$ Norway $^{12}$ and the USA publish data on:

- The source of referrals

Australia, England and the USA publish data on:

- the outcome of referrals (that is whether investigations are closed, remain open or are dealt with by other means ${ }^{13}$ in Australia, or 'screened in' or 'screened out' in the USA). The outcome of referrals in England can be extrapolated from data on referrals progressing to an initial assessment.

Norway is the only country that publishes details on need at this early stage in the child protection process. Categories include: inadequate care/abuse, conditions in the home, child's behavioural problems. In England data on needs is captured at the point when a child starts to receive services (CIN Census data).

\footnotetext{
${ }^{11}$ For investigated cases only

12 See above

13 Provision of advice or signposting to other services
} 


\section{Comparability of data}

\section{Numbers of referrals/notifications}

There are variations in how referrals are defined and the point at which data are collected (Annex Two). Data may be presented on:

- All cases received by children's social care (England, USA ${ }^{14}$, some Australian territories, Finland)

- Those cases deemed to require further assessment or investigation (following a preliminary screening process) (USA, some Australian territories, Norway)

- Cases that are substantiated and progress further (USA, Canada)

This will influence the figures recorded; the earlier the data are collected the greater the likelihood of higher referral levels as there will have been no opportunity for cases to be screened out. Data on all cases received by children's social care are available from Australia (although not in all territories), England, Finland and the USA. This may aid comparisons. However, additional factors also need to be taken into account, including for example:

\section{- Mandatory reporting}

Research in Australia, Canada and the USA suggests that mandatory reporting increases the volume of referrals although many may not meet the threshold for further investigation (see Harries and Clare, 2002; Lonne et al., 2008; Mathews and Kenny, 2008).

- Whether referrals are confined to cases of suspected maltreatment or routinely include requests for services.

In England and Finland referrals include requests for services. In contrast, in the USA such requests (relating to children with lower levels of need) are normally routed to voluntary agencies and therefore (other things being equal) one would anticipate lower referral rates in the USA. While such factors may have a bearing

\footnotetext{
${ }^{14}$ The USA collects data on all cases and the numbers screened in and out
} 
on referral rates, determining the reasons for variations in rate at both national and international levels is problematic because of the large number of variables that may influence this and the potential for multiple interpretations of the data. For example, the higher rate of referral per 1000 children in Australia (see Table below) may be connected to the mandatory duty to report or higher levels of need. The reason why just over half of cases result in no further action may illustrate that practitioners are referring inappropriate cases and/or that high thresholds are in operation (and that some cases meeting the threshold are not being offered a service). Referral rates may also be influenced by policy developments. The National Framework for Protecting Australia's Children 2009-2020 (COAG 2009) emphasises the importance of early intervention and prevention. In order to explore the impact of policy developments such as this, data would need to be examined over time.

Table 4.3: Rates of referral per 1000 in sample countries and percentage resulting in no further action ${ }^{15}$

\begin{tabular}{|l|l|l|}
\hline Country & Referrals per $\mathbf{1 0 0 0}$ children & $\begin{array}{l}\text { Referrals that result in no } \\
\text { further action }\end{array}$ \\
\hline Australia & 67.9 & $51 \%$ \\
\hline England & 53.9 & $36 \%$ \\
\hline Finland & 45.5 & Not available \\
\hline USA & 44.1 & $38 \%$ \\
\hline
\end{tabular}

In England a combination of factors, including the Peter Connelly case, implementation of the Common Assessment Framework and current economic climate are thought to have contributed to a recent increase in the rate of referrals (Brookes, 2010; Holmes, Munro and Soper, 2010; ADCS, 2010). Figures from a national survey by the Association of Directors of Children's Services reveal that the demand for children's social care services has increased. Data for two quarters, October 2007- December 2007 and October - December 2009 (to take into account the period pre and post reporting on the Peter Connelly case), reveal a 16.5 per cent rise in the number of referrals to children's social care between October 2007 and December 2009 (Brookes, 2010).

\footnotetext{
${ }^{15}$ The figures cited draw on the latest available data for each country at $30^{\text {th }}$ October 2010. Further details are provided in Annex One.
} 
Brookes (2010) also suggests that, over the same period, there has been a fall in the number of cases requiring no further action and a rise in referrals progressing to initial assessment, with the proportion of initial assessments compared to the number of referrals increasing by four percentage points. Again, this reinforces the importance of considering findings with reference to the wider social policy context and the value of exploring trends over time rather than based on data for a single year.

\section{Source of referral}

Norway, Australia and the USA all collect information on the source of referrals that are investigated by child welfare services. Data may assist in exploring the impact of mandatory reporting on patterns of referral by professional group. The information collected may also be valuable in determining how the public and different professions respond to concerns that a child may have suffered, or is likely to suffer, significant harm and whether certain groups are reluctant to report. For instance, research in England demonstrates that professionals in adult services, who focus on parents' problems, such a psychiatrists, psychologists and alcohol and substance misuse workers are reluctant to refer to children's social care (Davies and Ward, forthcoming). Detailed information on sources of referral is requested in Norway, Australia and the USA; although classification systems do not map exactly there are a number of common categories including: child, parent(s), friends or neighbours, children welfare services, health, the police and education professionals.

England does not publish data on sources of referral at a national level but these data have been found to be valuable in illuminating the impact of the death of Peter Connelly on referral rates and the decisions taken by the public and professionals concerning whether or not they should refer a child to children's social care. The ADCS collated data from 56 out of 152 (37\%) local authorities on the proportion of total referrals received from parents, carers or family members, health, the police, education professionals and all other referrers (ADCS, 2010). Table 4.4 presents data on sources of referral. 
Table 4.4: Sources of referral to children's social care ${ }^{16}$

\begin{tabular}{|l|l|l|l|l|}
\hline & Australia & England & Norway & USA \\
\hline Child & $0.3 \%$ & Not available & $1.5 \%$ & $0.5 \%$ \\
\hline Parent & $7 \%$ & $\begin{array}{l}11.1 \% \text { (inc. other } \\
\text { family) }\end{array}$ & $15 \%$ & $7 \%$ \\
\hline $\begin{array}{l}\text { Other family (inc. } \\
\text { siblings) }\end{array}$ & $6 \%$ & Not available & $3 \%$ & $7 \%$ \\
\hline Neighbours & $3.9 \%$ & Not available & $2.4 \%$ & $5.1 \%$ \\
\hline $\begin{array}{l}\text { Child welfare } \\
\text { services }\end{array}$ & $1.4 \%$ & Not available & $20.4 \%$ & $10.6 \%$ \\
\hline Health & $16.2 \%$ & $13 \%$ & & $12.5 \%$ \\
\hline Police & $28 \%$ & $23.5 \%$ & $9.1 \%$ & $16.3 \%$ \\
\hline Education & $11.9 \%$ & $12.8 \%$ & $11.2 \%$ & $16.9 \%$ \\
\hline Kindergarten & $1.4 \%$ & Not available & $4 \%$ & $0.9 \%$ \\
\hline Foster care & Not available & Not available & Not available & 0.6 \\
\hline providers & & & $14.2 \%$ & $8.1 \%$ \\
\hline All others & $17.5 \%$ & $39.6 \%$ & Not available & 14.5 \\
\hline Not known & $5.2 \%$ & & & \\
\hline
\end{tabular}

In Australia, England and the USA a high proportion of referrals are made by health professionals and the police. The pattern in Norway differs and referrals from child welfare services (20.4\%) followed by education (19.2\%) and parents $(15 \%)$ are most common. This is likely to reflect the less adversarial and family support orientated child welfare system in Norway (Gilbert et al., 2009; Hetherington and Katz, 2006).

\section{Assessments and substantiation of abuse}

\section{Availability of data}

Following referral, decisions have to be taken about whether further action is required to support families and/or safeguard children from harm. Table 4.5 below shows the data items relating to assessments and investigations that are collated on a national basis by two or more countries.

\footnotetext{
${ }^{16}$ The figures cited draw on the latest available data for each country at $30^{\text {th }}$ October 2010. Further details are provided in Annex One.
} 
Table 4.5: Assessment and investigation data items collected by two or more countries

\begin{tabular}{|l|l|l|l|l|l|l|l|}
\hline Data item & Aus & Can & Den & Eng & Fin & Nor & USA \\
\hline Total carried out & Yes & Yes & No & Yes & Yes & Yes & Yes \\
\hline $\begin{array}{l}\text { Response time (from referral to } \\
\text { investigation) }\end{array}$ & Yes & No & No & No $^{17}$ & No & No & Yes \\
\hline By area/region/municipality/state & Yes & Yes & No & Yes & Yes & Yes & Yes \\
\hline Child age and gender & Yes & Yes & No & No $^{18}$ & No & Yes & Yes \\
\hline Outcome/substantiation & Yes & Yes & No & Yes $^{19}$ & No & Yes & Yes \\
\hline Category of abuse & Yes & Yes & No & No & No & No $^{20}$ & Yes \\
\hline Intimate partner violence & No & Yes & No & No & No & No & Yes \\
\hline Alleged perpetrator & No & Yes & No & No & No & No & Yes \\
\hline Perpetrator age & No & No & No & No & No & No & Yes \\
\hline Household structure & Yes & Yes & No & No & No & No & No \\
\hline Previous investigations & No & Yes & No & No & No & No & Yes \\
\hline
\end{tabular}

Every country except Denmark collects data on:

- Total number of assessments/investigations undertaken (including a breakdown by region)

Australia, Canada, England, Norway and the USA collect data on:

- The outcome of the assessment(s) (substantiation in Australia, Canada and the USA, service responses in England and Norway).

Australia, Canada and the USA collect data on:

- Category of abuse

\footnotetext{
${ }^{17}$ Data are not collected on the timeframe from referral to assessment but are collected on the number of initial and core assessments completed within statutory timescales. The CIN Census 2010 was published shortly after this report was submitted. This statistical return does include data on response time.

${ }^{18}$ Child age and gender are collected for the CIN Census 2010.

${ }^{19}$ One of the needs codes in the English CIN census is 'abuse and neglect' but data are not available on categories of abuse at this stage in the child protection process. In both England and Norway these data are collected post assessment.

${ }^{20}$ See above.
} 
In Norway and England data on the type of abuse children and young people have suffered, or are likely to suffer, are collected at the next stage in each country's safeguarding procedures.

\section{Comparability of the data}

\section{Number of assessments}

Data on the number of assessments undertaken by authorities are presented below. However, explaining the reasons for the differences in rates of assessment per 1000 is challenging. In the USA and Australia decisions concerning what progresses to assessment vary between states and territories. Even when practitioners are operating within the same legal framework and following the same statutory guidance there may still be variations between authorities in referrals progressing to assessment and in outcomes. This not only relates to socio-demographic factors and levels of deprivation but also to operational issues, including the availability of support services and the culture within authorities and individual teams (Holmes, Munro and Soper, 2010).

\section{Table 4.6: Number and rate of assessments undertaken in sample}

\section{countries $^{21}$}

\begin{tabular}{|l|l|l|}
\hline Country & Number of assessments & Rate per $\mathbf{1 0 0 0}$ \\
\hline Australia & 203,225 & 40.7 \\
\hline Canada & 234,842 & 39.2 \\
\hline England (initial assessment) & 390,600 & 34.6 \\
\hline $\begin{array}{l}\text { England ('core'/in-depth } \\
\text { assessment) }\end{array}$ & 141,500 & 12.6 \\
\hline Finland (in-depth assessment) & 15,042 & 13.7 \\
\hline Norway & 29,412 & 26.4 \\
\hline USA & $1,996,774$ & 27.1 \\
\hline
\end{tabular}

England and Finland have a multi-tier assessment process whereby an initial assessment is undertaken to inform decisions as to whether a more in-depth (core) assessment is required. In both countries more in-depth assessments

\footnotetext{
${ }^{21}$ The figures cited draw on the latest available data for each country at $30^{\text {th }}$ October 2010. Further details are provided in Annex One.
} 
may be undertaken to determine the needs of the child and factors affecting parenting capacity to inform professional judgements on the types of services that might be provided. These assessments are not confined to cases where there are concerns a child is suffering, or likely to suffer, significant harm. The rates per 1000 were not dissimilar; 12.6 per 1000 children in England and 13.7 in Finland.

\section{Outcome of assessments}

In Australia, Canada and the USA there are specific data items on whether alleged abuse has been substantiated post assessment. In England, children who are the subject of a child protection plan are deemed to have passed the threshold to be classified as 'substantiated cases' (agencies judge that a child may continue to suffer, or is likely to suffer, significant harm).

Analysis of substantiation data revealed that between $0.3 \%$ (England) and 1.3\% (USA) of the total population of children had maltreatment substantiated.

\section{Table 4.7: Substantiation of abuse ${ }^{22}$}

\begin{tabular}{|l|l|l|}
\hline Country & $\begin{array}{l}\text { Number of cases substantiated (by } \\
\text { children's services in a given year) }\end{array}$ & $\begin{array}{l}\text { Cases substantiated as a } \\
\text { percentage of the child population }\end{array}$ \\
\hline Australia & 54,621 & $1 \%$ \\
\hline Canada & 235,842 & $1 \%$ \\
\hline England & 44,500 & $0.3 \%$ \\
\hline USA & 101,8406 & $1.3 \%$ \\
\hline
\end{tabular}

The lower rate in England may reflect the fact that harm may be substantiated without a child becoming the subject of a child protection plan, if it is judged that they are not continuing to, or to be likely to suffer, significant harm in the future; thus under-recording the number of children for whom abuse or neglect has been substantiated. Consideration also needs to be given to the wider range of services available to support both children in need and those who have suffered significant harm.

\footnotetext{
${ }^{22}$ The figures cited draw on the latest available data for each country at $30^{\text {th }}$ October 2010 . Further details are provided in Annex One.
} 


\section{Provision of community-based services (largely for children remaining with their families)}

\section{Availability of data}

Table 4.8 below provides an overview of data collected in each country concerning children in receipt of child welfare or protection services in the community.

Table 4.8: Data items collected by two or more countries relating to community-based services (children remaining with their families)

\begin{tabular}{|l|l|l|l|l|l|l|l|}
\hline Data item & Aus & Can & Den & Eng & Fin & Nor & USA \\
\hline Total children/families & Yes & Yes & Yes & Yes & Yes & Yes & Yes \\
\hline Area/region/municipality/state & No & No & Yes & Yes & No & No & No \\
\hline Type of abuse & No & No & No & Yes & No & Yes & No \\
\hline Previously received services & No & No & No & Yes & Yes & No & No \\
\hline Length of time in receipt of services & No & No & No & Yes & No & No & Yes \\
\hline Type of intervention & No & No & Yes & No & Yes & Yes & No \\
\hline
\end{tabular}

There are challenges in undertaking meaningful analysis of the data that are collected at this stage due to variations in the child populations being served and in the nature of the services that are provided. The lack of detailed data on the types of services provided (with the exception of Norway) exacerbates this problem. The European systems generally offer support to meet the needs of children with lower level of need than is the case in the more child-protection orientated systems of Australia, Canada and the USA. In England the CIN census provides data on all children in need (referred to and assessed by children's social care services, including those who are the subject of a child protection plan). Separate data are also collected on children who are the subject of a child protection plan. In Norway and Finland, data are supplied on numbers receiving 'assistance in the home ${ }^{23}$ and those subject to 'client plans' but it is not possible to differentiate between services for children and young people with lower levels of need and child protection cases ${ }^{24}$. For example, the type of assistance offered in Norway may include provision of leisure activities or

\footnotetext{
${ }^{23}$ In Norway this may include out-of-home placements providing a formal decision to place the child in care has not been taken.
} 
economic assistance through to much more intensive support. Therefore, it is problematic to compare Finland and Norway's data with countries that supply data on child protection services alone. This is reflected in the data, as Table 4.9 below shows. Findings highlight the fact that the existence of seemingly similar variables is not enough; the data need to be treated with caution to avoid drawing erroneous conclusions.

Table 4.9: Number and rate of children subject to plans and services ${ }^{25}$

\begin{tabular}{|c|c|c|}
\hline Country & $\begin{array}{l}\text { Number subject to plans or } \\
\text { services }\end{array}$ & Rate per 1000 \\
\hline Australia & 15,544 & 3.1 \\
\hline Canada & 62,715 & 10.4 \\
\hline Denmark & 11,537 & 9.5 \\
\hline England (children in need) & 382,300 & 33.9 \\
\hline $\begin{array}{l}\text { England (the subject of a child } \\
\text { protection plan) }\end{array}$ & 35,700 & 3.1 \\
\hline Finland & 67,347 & 61.2 \\
\hline Norway & 35,641 & 31.9 \\
\hline USA (preventative) ${ }^{26}$ & $2,750,598$ & 43.5 \\
\hline USA (post investigation) ${ }^{27}$ & 883,252 & 17.6 \\
\hline
\end{tabular}

\section{Looked after children/ out-of-home care}

Availability of data

Table 4.10 below provides a summary of the data two or more countries collect on children in out-of-home care.

\footnotetext{
${ }^{25}$ The figures cited draw on the latest available data for each country at $30^{\text {th }}$ October 2010. Further details are provided in Annex One.

${ }^{26}$ Children at risk

${ }^{27}$ Substantiated
} 
Table 4.10: Data items collected by two or more countries relating to looked after children/children in out-of-home care

\begin{tabular}{|l|l|l|l|l|l|l|l|}
\hline Data item & Aus & Can & Den & Eng & Fin & Nor & USA \\
\hline $\begin{array}{l}\text { Total number of children in out- } \\
\text { of-home care }\end{array}$ & Yes & Yes & Yes & Yes & Yes & Yes & Yes \\
\hline Area/region & Yes & Yes & Yes & Yes & No & Yes & No \\
\hline Legal status & Yes & Yes & No & Yes & No & No & No \\
\hline Placement type & Yes & Yes & Yes & Yes & Yes & Yes & Yes \\
\hline $\begin{array}{l}\text { Children starting to be looked } \\
\text { after in a given year }\end{array}$ & Yes & No & Yes & Yes & No & No & Yes \\
\hline $\begin{array}{l}\text { Children starting to be looked } \\
\text { after for the first time }\end{array}$ & Yes & No & Yes & Yes & No & No & No \\
\hline $\begin{array}{l}\text { Total ceasing to be looked } \\
\text { after }\end{array}$ & Yes & No & No & Yes & No & No & No \\
\hline
\end{tabular}

Every country collects data on the number of looked after children within their respective systems on a given date (in care/snapshot data). Australia, Denmark, England and the USA collect data on entrants to care each year (entrants or flow population) (see Thoburn, 2007). Every country also collects data on the placements that children and young people are living in, including foster care (either kinship and/or stranger) and residential settings (which may serve different populations and offer different levels of therapeutic intervention in different countries) (see Fernandez and Barth, 2010).

\section{Comparability}

Definitions of looked after children may include a combination of children voluntarily placed away from home and those on legal orders or simply the latter. Temporary stays in the form of respite may be included or excluded from the statistics. In England it is also possible for children to be looked after but living with their parents. Variations such as these will influence the number of children looked after. Similarities and differences in legal frameworks and ideological positions on the use of out-of-home care, as well as economic factors will also influence the figures and rates per 1000 of looked after children (Munro et al., 2005; Ward, 2008). In Australia, Canada, USA and England entry to care is generally viewed as a short term measure with emphasis placed on rehabilitation home. Adoption is a permanency solution where this is not possible. In contrast, in Norway and Denmark, for example placement in out-of-home care may be 
viewed as a necessary part of family support (Thoburn, 2007). These issues will influence the number of children looked after and the flow of cases as Table 4.11 and 4.12 show.

Table 4.11: Number and rate of children in out-of-home care ${ }^{28}$

\begin{tabular}{|l|l|l|}
\hline Country & Number in out-of-home care & Rate per $\mathbf{1 0 0 0}$ children \\
\hline Australia & 34,057 & 6.8 \\
\hline Canada $^{29}$ & 19599 & 3.3 \\
\hline Denmark & 12747 & 10.5 \\
\hline England & 64400 & 5.7 \\
\hline $\begin{array}{l}\text { England (minus } \\
\text { placement with parents) }\end{array}$ & 60200 & 5.3 \\
\hline Finland & 16608 & 15.1 \\
\hline Norway & 9,328 & 8.4 \\
\hline USA & 186288 & 3.8 \\
\hline
\end{tabular}

Table 4.12: Number and rate of children entering care for the first time in a given year (new entrants) ${ }^{30}$

\begin{tabular}{|l|l|l|}
\hline Country & $\begin{array}{l}\text { Number of children placed } \\
\text { in out-of-home care for first } \\
\text { time in year }\end{array}$ & Rate per $\mathbf{1 0 0 0}$ children \\
\hline Australia & 12883 & 2.6 \\
\hline England & 27800 & 2.5 \\
\hline $\begin{array}{l}\text { England (minus } \\
\text { placement with parents) }\end{array}$ & 26600 & 2.4 \\
\hline Finland & 2554 & 2.3 \\
\hline
\end{tabular}

It is noteworthy that the rate per 1000 of new entrants to out-of-home in each country for which these data are available are similar (2.3 in Finland, 2.4 in England and 2.6 in Australia) but there are more noticeable differences in the total care populations (England 5.3, Australia 7.0 and Finland, 15.1 per 1000 children).

\footnotetext{
${ }^{28}$ The figures cited draw on the latest available data for each country at $30^{\text {th }}$ October 2010. Further details are provided in Annex One.

${ }^{29}$ In Canada data for children in care only relates to those placed directly following an initial investigation. Children referred for reason other than maltreatment are not included in the CIS2008 (Trocmé, 2010).

${ }^{30}$ The figures cited draw on the latest available data for each country at $30^{\text {th }}$ October 2010. Further details are provided in Annex One.
} 


\section{Conclusion}

At a national level each country collects data on their child welfare or protection system but neither Finland nor Denmark produce information concerning the types of abuse children have suffered. The depth and breadth of coverage and what is collected at key stages in the safeguarding process also varies between countries. For instance, in Canada the CIS provides comprehensive data on children subject to an investigation but it is not possible to determine what support or services are subsequently provided. In Australia, differences in reporting requirements and recording practices between Territories make interpretation of findings problematic. 'Snapshots' of the numbers of children receiving a particular service response may be misleading both because of differences in data collection points, thresholds and the client group served. Figures may also be influenced by changes in policy direction or public attitude rather than reflecting genuine differences in the prevalence of abuse of effectiveness of children's social care. It is essential that data are interpreted with caution and with reference to the wider social, political and economic context. 


\section{Chapter Five: Internationally collated data on child death and injury}

So far, the report has focused on exploration of the availability and comparability of national datasets to examine the prevalence of abuse and neglect. This Chapter focuses exclusively on discussion and presentation of data on child death and injury utilising data collated at an international level. Information on all causes of infant mortality are presented but as the study is primarily concerned with safeguarding children suffering, or likely to suffer, significant harm particular attention is paid to data on intentional injury and deaths due to negligence, maltreatment or physical assault.

Child deaths and/or injury may be caused by a range of factors; only in the minority will abuse or neglect be a contributory factor. However, the numbers who die or suffer injury as a result of maltreatment are substantially underreported because the cause is not always correctly attributed (UNICEF, 2003). Caution is needed in comparing figures because of differences in the definitions employed by different countries and/or states concerning what constitutes a maltreatment death or injury and because the causes may be misclassified by practitioners. Although deaths due to severe physical injury may be easily recognised, certain types of injury are more difficult to detect, including for example, infanticide - due to asphyxiation from smothering or drowning (Sidebotham and Fleming, 2007). Neglect may also contribute to some unintentional deaths, including drowning, fires and poisoning (Hymel, 2006). Effective procedures for investigating and monitoring all known and suspected child deaths due to injury will facilitate accurate recording of intentional and unintentional injuries and maximise opportunities for agencies and individuals to learn lessons to improve the way they work to safeguard children from harm.

\section{The European Injury Database}

A European Injury Database (IBD) has been developed providing accident and injury data from selected hospital emergency departments. This complements 
existing data sources such as routine causes of death statistics, hospital discharge registers and data on specific types of injury, including for example, road accidents. In 2006 the IDB Violence Module was introduced to record injuries attributed to child abuse. However, in practice few cases have been registered, thereby preventing meaningful analysis. The IDB 2009 report, Injuries in the European Union: statistics summary 2005-2007 does include a section on violence against children resulting in fatal and non-fatal injury at a European level. Denmark, Finland and the UK supplied data. Work is currently underway to develop the IDB Violence Module further and this may increase the scope for comparative analysis of non-fatal child injuries as a result of abuse and neglect (Bauer and Steiner, 2009).

\section{Infant mortality - All causes}

The World Health Organisation (WHO) and the Organisation for Economic Cooperation and Development (OECD) collate data on child mortality which assists with exploration of similarities and differences in rates of child death between countries.

Table 5.1 shows infant mortality from all causes (between birth and age one) for the seven countries included in the study. Ranking countries from 1-7 (lowest to highest rates of mortality) revealed that the $U^{31}$ ranked joint fifth alongside Canada. The highest recorded mortality rate was in the USA.

\footnotetext{
${ }^{31}$ Separate data for England were not available.
} 
Table 5.1: Infant mortality rate (probability of dying between birth and age one per 1,000 live births), 2008

\begin{tabular}{|l|l|l|l|l|}
\hline Country & Male & Female & All & $\begin{array}{l}\text { Ranking } \\
\text { (1=lowest } \\
\text { =highest })\end{array}$ \\
\hline Australia & 5 & 4 & 4 & 3 \\
\hline Canada & 6 & 5 & 5 & 5 \\
\hline Denmark & 4 & 3 & 4 & 3 \\
\hline Finland & 3 & 2 & 3 & 1 \\
\hline Norway & 3 & 2 & 3 & 1 \\
\hline UK & 5 & 4 & 5 & 5 \\
\hline USA & 7 & 6 & 7 & 7 \\
\hline
\end{tabular}

Source: WHO (2008) http://apps.who.int/gho/indicatorregistry/App_Main/view_indicator.aspx?iid=1

Findings in relation to infant mortality for children aged under five revealed a similar picture. The UK ranked joint fifth alongside Canada with a mortality rate of 6 per 1,000 live births. The USA had the highest mortality at 8 per 1,000 live births.

Table 5.2: Under five mortality (probability of dying by age 5 per 1,000 live births), 2008

\begin{tabular}{|l|l|l|l|l|}
\hline Country & Male & Female & All & $\begin{array}{l}\text { Ranking } \\
\text { (1= lowest 7= } \\
\text { highest) }\end{array}$ \\
\hline Australia & 6 & 5 & 5 & 4 \\
\hline Canada & 7 & 6 & 6 & 5 \\
\hline Denmark & 5 & 4 & 4 & 3 \\
\hline UK & 6 & 5 & 6 & 5 \\
\hline Finland & 4 & 3 & 3 & 1 \\
\hline Norway & 4 & 3 & 3 & 1 \\
\hline USA & 9 & 7 & 8 & 7 \\
\hline
\end{tabular}

Source WHO (2008): http://apps.who.int/gho/indicatorregistry/App Main/view indicator.aspx?iid=7

\section{Injuries and 'other' causes of death in children aged under five}

Table 5.3 (below) shows the distribution (as percent) of deaths caused by injuries and 'other' causes in children under five ${ }^{32}$. The UK had the lowest percentage of deaths due to injuries alongside Denmark (4.1\%) and the second lowest percentage of deaths attributed to 'other causes'.

\footnotetext{
${ }^{32}$ Deaths due to HIVIAIDS, diarrhoea, measles, malaria, pneumonia, prematurity, birth asphyxia, neonatal sepsis and congenital abnormalities have been excluded
} 
Table 5.3: Cause of death among children aged under five due to injuries and 'other' causes, distribution of cases (\%), 2008

\begin{tabular}{|c|c|c|c|c|c|}
\hline Country & Other & Injuries & $\begin{array}{l}\text { Total (Others } \\
\text { +Injuries) }\end{array}$ & $\begin{array}{l}\text { Ranking for } \\
\text { Injuries } \\
\text { (lowest to } \\
\text { highest) }\end{array}$ & $\begin{array}{l}\text { Ranking for } \\
\text { Others and } \\
\text { Injuries } \\
\text { (1=lowest 7= } \\
\text { highest) }\end{array}$ \\
\hline Australia & 32.8 & 7.8 & 40.6 & 5 & 7 \\
\hline Canada & 27.1 & 5.8 & 32.9 & 3 & 4 \\
\hline Denmark & 19.7 & 4.1 & 23.8 & 1 & 1 \\
\hline Finland & 24.5 & 6.5 & 31 & 4 & 3 \\
\hline Norway & 26 & 8.8 & 34.8 & 6 & 5 \\
\hline UK & 23 & 4.1 & 27.1 & 1 & 2 \\
\hline USA & 25.8 & 11.4 & 37.2 & 7 & 6 \\
\hline
\end{tabular}

Source WHO: http://apps.who.int/gho/indicatorregistry/App Main/view indicator.aspx?iid=89

\section{Negligence, maltreatment or physical assault}

Deaths due to negligence, maltreatment and physical assault for children and young people aged 0 to 19 are shown in Table 5.4 (below). The UK rate was 0.24 per 100,000. This was the lowest within the sample of countries but caution is needed in interpreting the data because in England there are a number of deaths registered each year where the cause of death is undetermined or yet to be determined; these may at a later date be reclassified as having been caused by negligence, maltreatment or physical assault. The USA had the highest rate at 3.67. However, the percentage of UK deaths that occurred in the home environment was second highest amongst the countries sampled (36 per cent). 
Table 5.4: Child death rates due to negligence, maltreatment or physical assault, children $0-19$ years old

\begin{tabular}{|c|c|c|c|c|c|}
\hline $\begin{array}{c}\text { Country and } \\
\text { Year of Data } \\
\text { Collection }\end{array}$ & $\begin{array}{c}\text { Rate } \\
\text { (per 100 000) }\end{array}$ & No of cases & $\begin{array}{c}\text { \% of at } \\
\text { home cases }\end{array}$ & $\begin{array}{c}\text { Ranking of } \\
\text { rates } \\
\text { (1 =lowest 7= } \\
\text { highest) }\end{array}$ & $\begin{array}{c}\text { Ranking of } \\
\text { at home } \\
\text { cases } \\
\text { (1= lowest 7= } \\
\text { highest) }\end{array}$ \\
\hline $\begin{array}{c}\text { Australia } \\
(2003-2005)\end{array}$ & 0.50 & 27 & 30 & 5 & 5 \\
\hline $\begin{array}{c}\text { Canada } \\
(2002-2004)\end{array}$ & 0.90 & 71 & 8 & 6 & 4 \\
\hline $\begin{array}{c}\text { Denmark } \\
(2004-2006)\end{array}$ & 0.40 & 5 & 0 & 3 & 1 \\
\hline $\begin{array}{c}\text { Finland } \\
(2006-2008)\end{array}$ & 0.33 & 4 & 0 & 2 & 1 \\
\hline $\begin{array}{c}\text { Norway } \\
(2005-2007)\end{array}$ & 0.49 & 4 & 0 & 4 & 1 \\
\hline $\begin{array}{c}\text { UK } \\
(2005-2007)\end{array}$ & 0.24 & 35 & 36 & 1 & 6 \\
\hline $\begin{array}{c}\text { USA } \\
(2003-2005)\end{array}$ & 3.67 & 2991 & 45 & 7 & 7 \\
\hline
\end{tabular}

Source OECD (2010): http://www.oecd.org/dataoecd/30/25/45583295.xls

See also for further details: http://www.oecd.org/document/4/0,3343,en 264934819378369961111 1,00.html

\section{Cause of death in children and young people under 14}

Table 5.5 provides details on mortality rates by cause in children and young people under 14. The data are taken from the full list of causes compiled by the WHO for 2004 (the latest available data source). For all causes of death (which includes illness and disease) the UK rate $(44.6$ per 100,000$)$ is the second highest after the US (63 per 100,000). The other European countries, Norway, Finland and Denmark had the lowest mortality rates, with 34.7, 38.7 and 39.7 respectively.

If data on illness and disease are excluded and rates of unintentional and intentional injury are explored, the UK has the lowest unintentional injury rate amongst the sample and the second lowest intentional injury rate (after Norway) (see Tables 5.5 and 5.6). Unintentional causes include, for example, deaths due to road traffic accidents or drowning. Intentional causes include: self-inflicted injuries and violence perpetrated against a child. Based on the data, the UK had the lowest rate of self-inflicted injuries resulting in death relative to other countries 
in the sample but also had a relatively high rate of violence related deaths.

Grouping these two data items together to give a composite 'intentional injury' rating means the low rate of self-inflicted injury offsets the fact that the UK has the second highest violence ranking.

Table 5.5: Estimated causes of death; persons aged 0 to 14 (rates per 100,000), 2004

\begin{tabular}{|c|c|c|c|c|c|c|c|c|}
\hline $\begin{array}{c}\text { Cause of } \\
\text { Death }\end{array}$ & Australia & Canada & Denmark & Finland & Norway & UK & USA & $\begin{array}{l}\text { Rank } \\
\text { UK }^{33}\end{array}$ \\
\hline All causes & 42.9 & 43.2 & 39.7 & 38.7 & 34.7 & 44.6 & 63.0 & 6 \\
\hline All Injuries & 6.7 & 6.0 & 3.6 & 9.7 & 6.7 & 3.5 & 11.1 & 1 \\
\hline $\begin{array}{l}\text { All } \\
\text { Unintentional } \\
\text { injuries (sum of } \\
\text { items } 4 \text { to 9) }\end{array}$ & 5.7 & 5.0 & 3.0 & 8.7 & 6.3 & 2.9 & 8.9 & 1 \\
\hline $\begin{array}{l}\text { Road traffic } \\
\text { accidents }\end{array}$ & 2.5 & 2.0 & 1.5 & 1.5 & 1.1 & 1.3 & 3.6 & 2 \\
\hline Poisonings & 0.1 & 0.1 & 0.0 & 0.0 & 0.0 & 0.0 & 0.1 & 4 \\
\hline Falls & 0.1 & 0.1 & 0.1 & 0.3 & 0.0 & 0.1 & 0.2 & 5 \\
\hline Fires & 0.2 & 0.4 & 0.1 & 0.1 & 0.4 & 0.2 & 0.8 & 3 \\
\hline Drownings & 0.8 & 0.7 & 0.5 & 1.1 & 0.9 & 0.2 & 1.2 & 1 \\
\hline $\begin{array}{l}\text { Other } \\
\text { unintentional } \\
\text { injuries }\end{array}$ & 2.0 & 1.8 & 0.9 & 5.7 & 3.9 & 1.0 & 2.9 & 2 \\
\hline $\begin{array}{l}\text { All Intentional } \\
\text { injuries (sum of } \\
\text { items } 11 \text { to } 12, \\
\text { see note) }\end{array}$ & 1.0 & 1.0 & 0.6 & 1.0 & 0.4 & 0.6 & 2.2 & 2 \\
\hline $\begin{array}{l}\text { Self-inflicted } \\
\text { injuries }\end{array}$ & 0.4 & 0.5 & 0.2 & 0.5 & 0.3 & 0.1 & 0.5 & 1 \\
\hline Violence & 0.6 & 0.5 & 0.4 & 0.5 & 0.1 & 0.5 & 1.7 & 5 \\
\hline
\end{tabular}

Source WHO: http://apps.who.int/ghodata/

File: gbddeathdalycountryestimates_persons_age_2004.xls

${ }^{33}$ Rank refers to the ranking of UK relative to the other countries in the sample for each cause of mortality. Rank lowest to highest i.e. a ranking of 1 represents lowest mortality rate, 7 the highest. There appears to be a discrepancy in the published data for Australia as the sum of self-inflicted injuries and violence, 1.0332, is greater than the published value, 1.0080. 
Table 5.6: Ranking of all countries in the sample according to causes of death; persons aged 0 to 14, 2004 (ranked lowest to highest)

\begin{tabular}{|l|r|r|r|r|r|r|r|}
\hline Cause of Death & Australia & Canada & Denmark & Finland & Norway & \multicolumn{1}{|c|}{ UK } & \multicolumn{1}{c|}{ USA } \\
\hline All causes & 4 & 5 & 3 & 2 & 1 & 6 & 7 \\
\hline All Injuries & 5 & 3 & 2 & 6 & 4 & 1 & 7 \\
\hline $\begin{array}{l}\text { Unintentional } \\
\text { injuries }\end{array}$ & 4 & 3 & 2 & 6 & 5 & 1 & 7 \\
\hline $\begin{array}{l}\text { Road traffic } \\
\text { accidents }\end{array}$ & 6 & 5 & 4 & 3 & 1 & 2 & 7 \\
\hline Poisonings & 5 & 6 & 3 & 3 & 3 & 4 & 7 \\
\hline Falls & 4 & 3 & 2 & 7 & 1 & 5 & 6 \\
\hline Fires & 4 & 5 & 1 & 2 & 6 & 3 & 7 \\
\hline Drownings & 4 & 3 & 2 & 6 & 5 & 1 & 7 \\
\hline $\begin{array}{l}\text { Other } \\
\text { unintentional } \\
\text { injuries }\end{array}$ & 4 & & & & & & \\
\hline $\begin{array}{l}\text { Intentional } \\
\text { injuries }\end{array}$ & 6 & 4 & 1 & 7 & 6 & 2 & 5 \\
\hline $\begin{array}{l}\text { Self-inflicted } \\
\text { injuries }\end{array}$ & 4 & 6 & 3 & 5 & 1 & 2 & 7 \\
\hline Violence & 6 & 4 & 2 & 7 & 3 & 1 & 5 \\
\hline
\end{tabular}

\section{Conclusion}

Analysis revealed that death rates due to unintentional and intentional injury, negligence, maltreatment and physical assault in England were among the lowest, although mortality due to violence amongst 0-14 year olds (Table 5.5) was higher than in the other European countries. Overall, mortality due to injury and assault in the UK appear to be similar to that in other European countries in the sample and was generally lower than that of Australia, Canada and the USA. However, the percentage of deaths at home due to negligence, maltreatment and physical assault was the second highest amongst countries in the sample (36\%, Table 5.4). This could reflect a higher prevalence but equally it could reflect better recognition and more accurate recording.

Pritchard and Williams (2010) undertook analysis of changes in child mortality attributable to child abuse between the years 1974 and 2006 using the WHO data. They suggest that the significantly greater fall in child abuse related deaths (CARD) compared to deaths by other causes in England and Wales demonstrate 
that there have been developments in the English child protection system over the last thirty years, whereas in other countries, including the USA the reverse is true. However, the analysis does not include deaths with an undetermined intent and this may distort the findings. Further, other studies have concluded that despite improvements in child protection in western Europe and the USA there has been little decrease in child homicide rates (Fox and Zaeitz, 2007; WHO, 2008). 


\section{Chapter Six: Conclusion}

This initial scoping review to explore the availability and comparability of data on child death, injury and safeguarding revealed that currently key international organisations do not routinely collate and publish extensive datasets to facilitate cross-national comparisons. The quality and quantity of data collected at a regional or national level vary considerably; influenced by (among other things) different interpretations of the role and contribution such data can make to understanding the needs of the child population and its use as a tool for monitoring service provision or performance. Variations in legal frameworks (both within and between countries), operational definitions of abuse and safeguarding policies and procedures also have a bearing upon what data are collected and its comparability with that collected elsewhere.

A core set of data items were generally collected by sample countries, including data on children's characteristics, type of abuse (with the exception of Finland and Denmark), numbers referred and the source of referrals ${ }^{34}$, numbers assessed, receiving services and looked after (by region). Minimal data were available on the characteristics of families involved with children's services or on factors affecting parenting capacity, although such data may be insightful to explore similarities and differences in subsequent service responses. Even when data are available the populations served within each child welfare or child protection system differ; few countries offering services to children and young people with varying levels of need collect and/or disaggregate information on these different groups in their statistical returns. Making valid cross-national comparisons is therefore not without challenges but exploration of the data with reference to the systems and processes in place in different jurisdictions does maximise the scope to interpret variations and explore what lessons could be learnt from elsewhere.

Although this study focused predominately on issues concerning the availability and comparability of data there is potential to undertake further work to:

${ }^{34}$ England's statistical returns do not include this as a data item 
- Provide a fuller interpretation of the data that are available (and already organised in the database) and to examine similarities and differences in the proportions of cases progressing through key safeguarding processes in the seven countries in the sample.

- Analyse trends over time and to consider the findings with reference to key events (such as child death tragedies) or policy developments which may precipitate changes in the recognition of and/or responses to children in need or those suffering, or likely to suffer, significant harm. This would offer an insight into the impact of key changes resulting from key developments in English policy and practice as well as how these compare with other countries that may have adopted either similar or different strategies.

- Develop the database further to include additional countries

- Access appropriate datasets (for example, from the USA and Norway) to undertake more complex analysis.

Findings also reinforce the importance of in-depth qualitative research alongside analysis of quantitative data to ensure that the data presented can be meaningfully compared. 


\section{Appendices}

\section{Annex One}

\section{Sources of Data}

All the data presented in this report have been extracted from publically available datasets or reports on child abuse and neglect. The years of data collection and publication for each country are presented in the table below.

Year of data collection and publication

\begin{tabular}{|l|l|l|}
\hline Country & Year of data collection & Year of publication \\
\hline Australia & $30^{\text {th }}$ July $-30^{\text {th }}$ June 2008-9 & January 2010 \\
\hline Canada & 2008 & October 2010 \\
\hline Denmark & 2008 & July 2010 \\
\hline England & $\begin{array}{l}1^{\text {st }} \text { April } 2008-31^{\text {st }} \text { March } 2009 \\
\left(\text { CPR3)/or where stated } 1^{\text {st }} \text { April }\right. \\
2009-31^{\text {st }} \text { March } 2010(C I N \\
\text { census provisional release) } .\end{array}$ & $2009 / 2010$ \\
\hline Finland & 2008 & 2009 \\
\hline Norway & 2009 & 2010 \\
\hline USA & 2008 & 2010 \\
\hline
\end{tabular}

\section{Australia}

The most recent report providing aggregate data on each state or territory in Australia was published in January 2010 and includes data from $1^{\text {st }}$ July to $30^{\text {th }}$ June 2008-2009.

The report can be accessed using the following link:

http://www.aihw.gov.au/publications/index.cfm/title/10859

\section{Canada}

The Canadian Incidence Study of Reported Child Abuse and Neglect (CIS) is conducted every five years. Data from the CIS-2008 are used in this report. 
The CIS-2008 can be accessed using the following link:

http://www.phac-aspc.gc.ca/publicat/cisfr-ecirf/index-eng.php

\section{Denmark}

Child level data is collected and collated by Statistics Denmark. The most recently published data which has been used in this report is for 2008 .

The data used for this report can be found at:

http://www.statbank.dk/statbank5a/default.asp?w=1280

\section{England}

The Department for Education collect and collate data from every local authority on an annual basis. Data on children who are the subject of a child protection plan and looked after were available for year ending 31 March 2009. Where possible Children in Need (CIN) census data were extracted from the provisional 2009-10 CIN census for the year ending $30^{\text {th }}$ March 2010. The full CIN Census return for 2010 was published in November shortly after this report was submitted.

This data can be accessed via:

http://www.dcsf.gov.uk/rsgateway/catego.shtml\#m9

\section{Finland}

The National Institute of Health and Welfare collect and collate data from each municipality on an annual basis. This is published in an annual report - Child Welfare. Data from 2008 were available.

This report can be accessed via the following link: http://uusi.sotkanet.fi/portal/page/portal/etusivu 


\section{Norway}

Statistics Norway collects and publishes data every year. Data from 2009 has been used in this report.

A link to the data can be found at:

http://www.ssb.no/english/subjects/03/03/

\section{USA}

The National Child Abuse and Neglect Data System (NCANDS) collects, collates and publishes data from all states in an annual report - Child Maltreatment. The most recent publication in the series presents data collected in 2008.

his report can be accessed at the following link:

http://www.childwelfare.gov/systemwide/statistics/can.cfm 


\section{Annex Two}

\section{Safeguarding policies and procedures by country}

\section{Australia}

\section{Overview of safeguarding children procedures and processes}

In Australia it is the responsibility of state and territory departments to safeguard children. There are significant differences in how jurisdictions deal with and report child protection issues, and therefore statistical comparisons between states and territories should be treated with caution. Each jurisdiction is responsible to provide assistance for vulnerable children who are suspected of being abused, neglected, harmed, or whose parents are unable to provide adequate care or protection.

The state and territory departments with responsibility for child protection and associated activities provide assistance to these children and their families through the provision of, or referral to, a range of services. Some of which are directed specifically towards children and families who are in need of protection, while others are available to a wider section of the population and attempt to deal with a broad range of issues.

It is mandatory to report suspected child abuse or neglect by anyone in some jurisdictions while in others certain professionals such as health professionals and education professionals are mandated to report suspicions.

Each state and territory in Australia has its own legislation, policies and practice in relation to child protection; however, the processes used to protect children are broadly similar (Bromfield and Higgins, 2005). These include:

- Reports to the department

- Notifications, investigations and substantiations

- Care and protection orders and out-of-home care

- Family support services. 


\section{Reports to the department}

Children who are assessed to be in need of protection can come into contact with state and territory child protection and support services through a number of avenues. These include reports of concerns about a child made by community members, professionals, organisations, the child, their parent(s) or another relative. These reports may relate to abuse and neglect or to broader family concerns such as economic problems or social isolation.

Reports are assessed, and either referred to another agency or the child protection and support services department may undertake an additional assessment to determine whether any further action is required. Reports requiring further action are generally classified as either as 'family support issues' or 'child protection notifications' 35 .

\section{Notifications, investigations and substantiations}

Child protection notifications take different forms depending upon which jurisdiction is handling them. In some area when an authorised department or body makes initial contact concerning an allegation of child abuse and neglect this is defined as a notification, whereas in others an initial screening process is conducted and only when a decision is taken that a child appears to needs protection is this defined as a notification. The department will then conduct an investigation to collect more detailed information about a child who is the subject of a notification and makes an assessment of the degree of harm or risk of harm for the child. After an investigation is completed, a notification will either be 'substantiated' or 'not substantiated'. During the process a decision will also be taken as to whether the child and family should be referred to family support services or other organisations or whether no further protective action is necessary or possible.

A notification will be substantiated where it is concluded after investigation that the child has been, is being or is likely to be abused, neglected or otherwise

\footnotetext{
${ }^{35}$ There are variations in the way that reports are classified in different jurisdictions
} 
harmed $^{36}$. States and territories differ somewhat in what they actually substantiate.

\section{Care and protection orders and out-of-home care}

At any time, from notification to post-investigation, the department responsible for a child can apply to court for a care or protection order. This action is only taken as a last resort in situations where continued involvement with the child is warranted. This may occur in situations where the family resists supervision and counselling, where other avenues for resolution of the situation have been exhausted, or where removal of a child into out-of-home care requires legal authorisation.

\section{Family support services}

Children and their families can be diverted from 'child protection' to 'family support services' at any time. Family support services may also be offered to complement other provisions for cases in which statutory intervention is ongoing.

\section{Data collection and monitoring}

The Australian Institute for Health and Welfare (AIHW) collate and publish annual statistics on child protection. The data is derived from administrative systems of the state and territory departments responsible for child protection according to nationally agreed definitions and counting rules. Each state and territory provides the AlHW with aggregate data on the following processes:

- Notifications, investigations and substantiations

- Care and protection orders

- Out-of-home care

- Intensive family support services

- Foster Carers

${ }^{36}$ Again, there are some variations in what different jurisdictions substantiate 


\section{Strengths and limitations}

Researchers are reliant on published, aggregate data and it is not possible to explore young people's profession through key stages of the child protection process. Further, although the processes used by the territories to protect children are broadly similar (Bromfield and Higgins 2005) there are some important differences that affect data comparability. For example, there are variations in how notifications are defined. Comparing performance between one jurisdiction and another is therefore problematic. Other differences include: the approaches adopted to manage reports on unborn children; whether or not substantiation focuses upon the harm suffered by the child or the incident or actions of the parent; and the quality of recording on indigenous groups.

\section{Developments in policy and practice}

The Committee on the Rights of the Child (2004) acknowledges that child abuse is a major concern despite ongoing efforts by Government and NGOs to address this. Australian NGOs suggest that rates of abuse and neglect within the family are too high and that services to help are inadequate. Expenditure on child protection and out-of-home care has increased and efforts are being made by the Council of Australian Governments (COAG) to facilitate a national effort to respond to child protection issues in relation to indigenous groups.

In 2009 COAG endorsed the National Framework for Protecting Australia's Children 2009-2020. This signals a commitment to achieving a substantial and sustained reduction in child abuse and neglect in Australia. The national framework emphasises the importance of early intervention and prevention and that child protection is a shared responsibility, within families, and across communities, professions, services, and governments.

\section{Canada}

\section{Overview of safeguarding children procedures and processes}

In Canada protecting and supporting children at risk of abuse and neglect falls under the jurisdiction of the 13 Canadian provinces and territories, and a system of child welfare organisations, which have responsibility for protecting and supporting Aboriginal children. There are variations in how these systems 
operate and in the legislative frameworks governing child welfare in the provinces and territories (Public Health Agency of Canada (PHAC), 2010). PHAC (2010) also highlight that there are differences in the:

...specific forms of maltreatment covered, procedures for investigation, grounds for removal, and timelines for determining permanent wardship (p.9).

However, there are similarities in the basic characteristics organised around the following processes:

- Reports of alleged maltreatment

- The provision of various types of counselling and supervision to families and children who may have suffered, or be at risk of, maltreatment.

- Looking after children in out-of-home care

\section{Data collection and monitoring}

The differences in each Canadian provinces and territories child welfare mandate make nation-wide data collection and monitoring of children and families in receipt of child welfare services problematic. In order to '... provide reliable estimates of the scope and characteristics of child abuse and neglect investigated by child welfare organisations in Canada the Canadian Incidence Study of Reported Child Abuse and Neglect (CIS) is conducted every 5 years ${ }^{37}$. Standardised definitions are employed to facilitate meaningful comparison of data from each province or territory.

The CIS-2008 collected in-depth information on a national sample of initial investigations (reports of possible child abuse or neglect, or risk of future maltreatment). The study does not include information about: unreported maltreatment; cases that are only investigated by the police; and reports that are made but subsequently screened out. The study provides data on (among other things): substantiation status; initial placements; and court applications. However, data collection is focused on initial investigations and longer term service events

${ }^{37}$ Three CIS have been carried out to date $(1998,2003,2008)$. 
are not tracked (PHAC, 2010 p.7). The figure below illustrates the scope of the CIS.

Figure 1: Scope of the CIS-2008

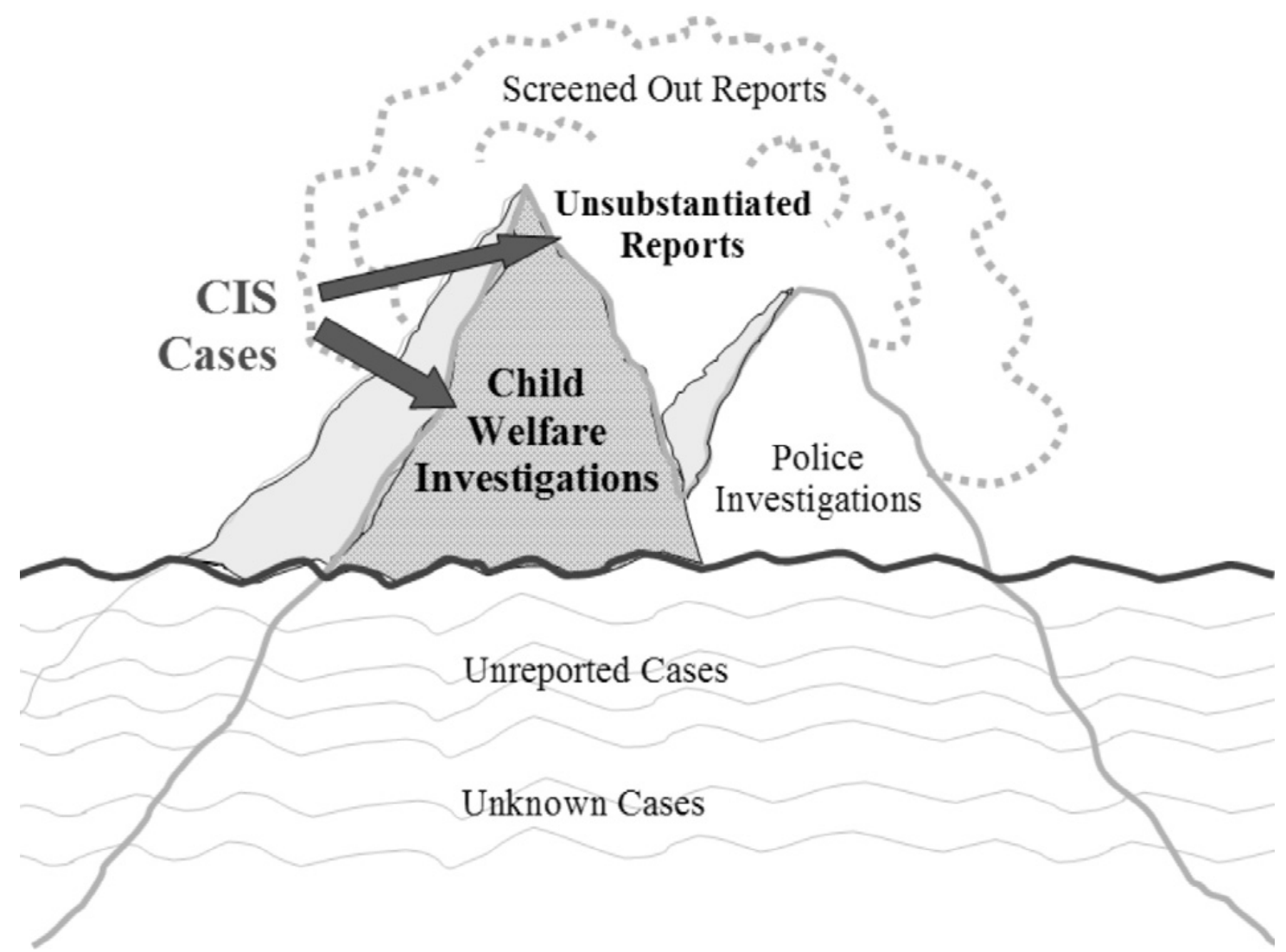

Adapted from Trocmé, McPhee, Tam and Hay (1994); and Sedlak and Broadhurst (1996).

\section{Developments in policy and practice}

The Canadian government have a long-term commitment to reduce family violence. The Family Violence Initiative (FVI) which began in 1991 and has permanent annual funding is aimed at addressing violence within 'relationships of kinship, intimacy, dependency or trust' (Public Health Agency of Canada website: http://www.phac-aspc.gc.ca/ncfv-cnivf/initiative-eng.php).

The FVI promotes public awareness of the risk and protective factors associated with family violence; works with government, research and community partners to strengthen the capacity of criminal justice, housing and health systems to respond; and supports data collection, research and evaluation efforts to identify innovative/promising practices and a range of effective interventions. 
A component of the $\mathrm{FVI}$ is the National Clearinghouse on Family Violence. This provides support for front line workers, health professionals, educators and law enforcement officers in the prevention and treatment of all forms of child abuse and neglect (Committee on the Rights of the Child, 2003).

\section{England}

\section{Overview of safeguarding children procedures and processes}

If there are concerns about a child's safety and welfare then the child, a relative or professional or any other member of the public may make a referral. A referral is defined as a request for services to be provided by children's social care. This is either; in respect of a case of a child not previously known to the local authority; or where a case was previously open but is now closed.

Following a referral to children's social care a decision is made about whether further action is required. If further action is required an initial assessment is undertaken. This is a brief assessment of the child to determine whether: the child is in need; there is reasonable cause to suspect the child is suffering, or is likely to suffer, significant harm; any services are required and of what types; and whether a further, more detailed core, assessment should be undertaken.

A more detailed core assessment may then be conducted to understand in depth the needs of the child and the capacity of their parents or caregivers to respond appropriately to these needs within their wider family and community network (HM Government, 2010).

\section{Children in Need}

In accordance with the Children Act 1989, a child is in need if:

- He/she is unlikely to achieve or maintain, or have the opportunity of achieving or maintaining, a reasonable standard of health or development without the provision for him/her of services by a local authority

- His/her health or development is likely to be significantly impaired, or further impaired, without the provision for him/her of such services; or 
- He/she is a disabled child.

\section{Child Protection Plans}

If there are concerns about the safety and welfare of a child then enquiries are made to decide if these concerns are substantiated. If it is judged that the child may continue to, or be likely to, suffer significant harm then children's social care services should convene a child protection conference. The child protection conference brings together family members, the child who is the subject of the conference (where appropriate) and those professionals most involved with the child and family.

The aim of the conference is for the professionals who are involved with the child and family to assess all the available information and decide how best to safeguard the child's welfare. If the conference concludes that the child is at continuing risk of harm, a multi-agency child protection plan is put in place. In order to make this decision the conference considers the evidence presented and takes into account the child's present situation and information about his or her family history and present and past family functioning; draw conclusions about the likelihood of the child suffering significant harm in future and decide whether the child is continuing to, or is likely to, suffer significant harm. The conference should consider whether the child has suffered significant harm, or is likely to suffer, significant harm in the future when determining if the child should be the subject of a child protection plan.

The criteria for deciding the likelihood of suffering harm in the future should be that either:

- The child can be shown to have suffered ill-treatment or impairment of health or development as a result of physical, emotional, or sexual abuse or neglect, and professional judgement is that further ill-treatment or impairment are likely; or

- Professional judgement, substantiated by the findings of enquiries in this individual case or by research evidence, is that the child is likely to suffer 
ill-treatment or the impairment of health or development as a result of physical, emotional, or sexual abuse or neglect (HM Government, 2010).

\section{Denmark}

Preliminary searches for data and information suggested that it would be of value to include Denmark in the sample. However, as more in-depth work was undertaken it became apparent that they do not collect data on the types of abuse children and young people experience and information on child welfare policies and procedures is not published in English. For completeness data on Denmark are included on the database and Tables wherever data are available.

Denmark's State Party Report to the UN Committee on the Rights of the Child (Committee on the Rights of the Child, 2010a) provides some details on some procedures and processes; and details of recent developments in policy and practice, as outlined below.

\section{Overview of procedures and processes}

The local authority is required to initiate an assessment of the following factors relating to a child or young person if they are thought to require special support:

- Development and behaviour

- Family

- School

- Health

- Leisure time activities and friendships

- Other relevant factors

During the course of the assessments the local authority must involve any professionals who already has some knowledge of the child or young person and/or their family. For example, this may involve health visitors, day-care staff, psychologists, teachers or others.

The assessment should lead to a reasoned decision as to whether there are grounds for implementing measures and, if so, the nature of such measures. The 
position of the custodial parent or other person having custody of the child or young person to the proposed measures must be indicated, and so must any conditions in the family or its environment likely to facilitate a resolution of the difficulties. Investigations must be completed within four months of when the authority becomes aware that a child or young person may be in need of special support. There is an expectation that pre-birth assessments will be undertaken when this is deemed necessary.

\section{Care plans}

On the basis of the assessment, the local authority must prepare a care plan for the child or young person. This care plan must state the objective of the initiatives as well as the measures required to achieve this objective. The plan must be based on the investigations made and set up ultimate and intermediate targets in relation to the child or young person's development, behaviour, family relations, school situation, health, leisure time, friendships and any other relevant factors. The care plan must also state the expected duration of the initiatives. In cases regarding placement, the care plan must also state the forms of support to be initiated separately for the family in connection with the child or young person's stay outside the home and in the time following the child or young person's return home. No more than three months after having initiated a measure in relation to a child, young person or expectant parents, the local authorities are required to assess whether the initiatives need to be changed and whether the care plan needs to be revised. Following this, the local authority must make such an assessment at intervals of no more than 12 months.

During a period when a child or young person is placed in alternative care, the local authority must offer to prepare a separate plan to support the parents. This plan must be revised no more than three months after the child or young person has been placed in care and then at intervals of no more than 12 months.

The types of interventions that can be offered include:

- Consulting assistance relating to the conditions of the child or young person 
- Practical, educational or other support in the home

- Family therapy or specific treatment of the child's or young person's problems

- Residential accommodation for both the custodial parent or other person having custody, the child or young person and other members of the family, with a foster family, at an approved facility or in an institution or in an accommodation facility

- A relief care arrangement with a network foster family, a foster family, at an approved facility or in a residential institution,

- Appointment of a welfare officer for the child or young person

- Appointment of a permanent contact person for the child or young person and for the whole family

- Placing the child or young person in a care facility outside the home

- Arrangement of in-service training of the young person with a public or private employer designed to provide counselling, treatment and practical or educational support.

\section{Developments in policy and practice}

The Care Placement Reform which was implemented in 2006 was a major overhaul of the rules governing special support to children and young people. The objective of the reform was to ensure that children placed in care would have the same opportunities as other children to enjoy the benefits of education, work and family life. A placement in alternative care must make a positive contribution to helping the child obtain a better future.

The Care Placement Reform made it a requirement for local authorities to set up a comprehensive children's welfare policy with a view to setting developing local cohesion between different sectors and agencies and to balance general preventive work and the targeted efforts aimed at children and young people in need of special support, including children with a physical or mental impairment. 
Finland

Overview of safeguarding children procedures and processes

The New Child Welfare Act in Finland came into force in 2008. Child Welfare is defined as:

'....an investigation of the need for child welfare measures, the provision of support in community care, emergency placement of the child and taking the child into care, as well as care and after-care related to these' (National Institute for Health and Welfare, 2009 p.41).

Core processes include:

- Child Welfare notifications (section 25)

- Initiation of proceedings in a child welfare case and the start of a client relationship (section 26)

- Investigating the need of child welfare (section 27)

- Client plan (section 30)

- Children's and young people's entitlement to after-care (section 75)

- Children placed outside of the home

The following paragraphs, based on the definitions outlined by the National Institute for Health and Welfare (2009), provide information on each of these processes.

\section{Child welfare notification (section 25)}

A wide range of authorities have a duty to notify children's social care if a child welfare investigation is needed, although others may submit notifications if they have concerns about a child's care or development. The municipal body responsible for children's social care services must keep a register of child welfare notifications and their content.

Initiation of proceedings in a child welfare case and the start of a client relationship (section 26)

When a social worker or child welfare worker receives a notification an assessment must be undertaken within seven days to determine whether an 
investigation into the child's need for welfare is required or whether no further action is necessary.

\section{Investigating the need for child welfare (section 27)}

The social worker responsible for the child's affairs must investigate; the assessment should include analysis of the circumstances in which the child is being brought up, the parents' capacity to provide adequate care, and the need for child welfare measures. The depth of the investigation will vary depending upon the circumstances of the case. A summary of the investigation will be drawn up and this will inform the decision on whether or not the child welfare client relationship ends or continues. Investigations should be completed no later than three months after the initiation of proceedings in the child welfare case.

\section{Client plan (section 30)}

A client plan must be drawn up for every child who is a child welfare client, unless an investigation identifies that only temporary advice and guidance are needed. The client plan will include reference to the particular circumstances of the case and matters that the plan seeks to address, including the child and family's support needs, the services to be put in place and timescales to meet the objectives of the plan. The client plan must be reviewed at least once a year.

\section{Data collection and monitoring}

The Institute for Health and Welfare in Finland is responsible for the collection of data related to child welfare. They publish a yearly report including data collected from all municipalities in Finland. This includes information on the number of children and young people placed in out-of-home care (following a decision of a Social Welfare Board); placement settings and the duration of placements; and number of children in receipt of community-base care (National Institute for Health and Welfare, 2009). While data on, children in out-of-home care, community based services and referrals is fairly comprehensive no data on the type of abuse children have suffered is collected or published. 


\section{Developments in policy and practice}

The new Child Welfare Act which was implemented in 2008 aims to promote consideration of the rights and best interests of the child. Emphasis is also placed on providing provision and support as early as possible. The Act also aims to improve cooperation among public authorities in the provision of regular services to improve the welfare of children and young people; and to improve children and parents participation in child protection decision-making processes (Committee on the Rights of the Child, 2010b).

\section{Norway}

\section{Overview of safeguarding children procedures and processes}

The main purpose of the child welfare service [in Norway] is to provide timely help and support to children and young people who live in conditions that may be harmful to their health or development, and to make sure they grow up in safe and secure surroundings' (Ministry of Children, Equality and Social Inclusion: website http://www.regjeringen.no/en/dep/bld/Topics/Child-welfare.html?id=1058)

The state, through the Ministry of Children and Equality, has overall responsibility for the child welfare system. Its administration is assigned to municipal child welfare services and the Norwegian Directorate for Children, Youth and Family Affairs. The responsibilities and tasks of child welfare authorities are regulated in the Act of 17 July 1992 No. 100 relating to child welfare services (Child Welfare Act).

The most important tasks of the child welfare authorities are to:

- Take care of vulnerable children. The child welfare service has a special duty to care for the most vulnerable children in society. It protects children from poor care and takes action to keep them from suffering physically and psychologically.

- Provide help and support. The child welfare service institutes assistive measures for children and families when the children have special needs due to conditions in the home. Help may be provided in the form of advice, guidance or assistive measures. Typical measures include personal 
contact support, parental relief within the home and enrolment of children in day care or kindergarten.

- Intervene when necessary. The child welfare service has a responsibility to intervene if measures in the home are not sufficient to meet the child's needs. In consultation with parents, the service may then arrange placement for a period of time in a foster home, parent/child programme or institution. If a child is to be placed outside the home without the parents' consent, the County Social Welfare Board is required to rule on the proposed placement after hearing the municipality's recommendation (Ministry of Children, Equality and Social Inclusion: website http://www.regjeringen.no/en/dep/bld/Topics/Child-welfare.html?id=1058).

Further details on the progression of cases through the child welfare system are outlined below.

\section{Reports}

A report is written when there is reason to believe that there are grounds for intervention pursuant to the Child Welfare Services Act. Data that are collected at this stage includes information on the source of the referral, reasons for referral for all children who the child welfare starts or closes an investigation on during the year.

\section{Investigations}

The child welfare service has the right and obligation to commence an investigation when there are reasonable grounds that a child may be living in circumstances warranting intervention under the Child Welfare Services Act. If several investigations about the same child are undertaken in the same year then only the first is registered.

\section{Assistance in the home}

Assistance in the home is intended as a preventative measure and may include (among other things), economic assistance, kindergarten, support for the child, supervision, respite. Under the new Child Welfare Act of 1993 children can be taken out of the home and placed, for example, in foster care without a formal 
decision to place the child in care. Such a placement under Section 4-4, fifth paragraph, will then be classified as assistance, not as care.

\section{Care}

Under the Child Welfare Services Act care is provided under Section 4-12 (Section 19 in the old Child Welfare Act). All decisions to place the child in care outside the home have to be made by the county social welfare board. Care is classified as intervention pursuant to Section 4-12 and includes emergency shelter homes, foster homes, children's homes, residential work collectives, psychiatric institutions, psychiatric hospitals or other care outside the home.

\section{Data collection and monitoring}

The production of official statistics in Norway is the responsibility of the Ministry of Children and Family Affairs pursuant to the Child Welfare Services Act 1992. Data collection is carried out by Statistics Norway on behalf of the Ministry.

Statistics are collected on all children placed under the protection of the child welfare authorities during the statistical year. Children with investigation cases started and closed during the statistical year are also included in the population. The child is therefore the statistical unit. Intervention in Norway can be undertaken for children under the age of 18 or existing intervention can be extended, with their consent until the young person reaches 23 years. The statistics that are produced contain information about:

...who reported the case that led to the investigation, the content of the report and the result of the investigation. The type of intervention (assistance in the home/care), the kind of intervention (1-23), and the number of months the intervention has been in effect during the statistical year are registered. Also registered is whether the parents have had their children taken away from them during the statistical year (Statistics Norway, 2008). 


\section{Developments in policy and practice}

The Ministry of Children and Equality have devised a strategy plan against sexual and physical abuse against children (2005-2009). The plan contains measures in the areas of prevention, uncovering, assistance and treatment, research, and improving skills (Committee on the Rights of the Child, 2009).

USA

\section{Overview of safeguarding children policy and procedures in the USA}

In the USA all 50 states, the District of Columbia and the U.S. Territories have mandatory reporting laws that require certain professionals and institutions to report suspected maltreatment to a child protective services (CPS) agency. Mandatory reporters include; health care providers and facilities, mental health care providers, teachers and other school staff, social workers, police officers, foster care providers, and day care providers. Referrals are then either 'screened-in' or 'screened-out' (U.S. Department of Health and Human Services, 2010).

Where reports are 'screened-in' an investigation or assessment is conducted by the CPS agency to determine the likelihood that maltreatment has occurred or that the child is at risk of maltreatment. Following this investigation the CPS makes a finding (disposition) of whether the child has been a victim or is at risk of abuse or neglect (U.S. Department of Health and Human Services, 2010).

\section{Data collection and monitoring}

In the USA data is collected across all states on children who are served by child protective services (CPS) agencies. The National Child Abuse and Neglect data System (NCANDS) supported by the Children's Bureau is responsible for collating and analysing this data (U.S. Department of Health and Human Services, 2010).

The NCANDS data is near-universal census sample of children who are reported to CPS throughout the United States at the case level. The NCANDS data is able to produce continuous trends data and examine trajectories of children as they re-enter CPS (Fluke, 2010). A limitation is that the data available is what is 
readily and consistently available from individual states. In addition, the comparability of NCANDS data is limited by the variability of definitions used by CPS agencies in operationally defining maltreatment.

Child Maltreatment 2008 (U.S. Department for health and Human Services, 2010) collate data on:

- Reports - referral and reports of child maltreatment

- Children - characteristics of victims and non-victims

- Fatalities - fatalities that occurred as a result of maltreatment

- Perpetrators - perpetrators of maltreatment

- Services - services to prevent maltreatment and to assist victims 


\section{References}

ADCS (2010) Safeguarding Pressures Report. Phase 2: Exploring reasons and effect. Association of the Directors of Children's Services. Available at:

http://www.adcs.org.uk/download/news/adcs-sg-pressures-p2-exec-summary.pdf

Alcock, P. (2001) 'The Comparative Context.' In P. Alcock and G. Craig (eds) International Social Policy. Basingstoke: Palgrave Macmillan.

Australian Institute of Health and Welfare (2010) Child Protection Australia 200809. Canberra: AlHW. Available at:

http://www.aihw.gov.au/publications/cws/35/10859.pdf

Bauer, R. and Steiner, M. (2009) Injuries in the European Union statistics summary 2005-2007. Vienna: Eurosafe and KfV. Available at:

https://webgate.ec.europa.eu/idb/documents/2009-IDB-Report_screen.pdf

Bromfield, L. and Higgins, D.J. (2005) 'National comparison of child protection systems.' Child Abuse Prevention Issues 23, 22.

Brookes, C. (2010) Safeguarding pressures projects: Results of data collection. London: Association of Directors of Children's Services.

ChildOnEurope (2009) Guidelines on Data Collection and Monitoring Systems on Child Abuse. Italy: Istituto degli Innocenti. Available at:

http://www.childoneurope.org/issues/publications/childabuse guidelines.pdf

Council of Australian Governments (2009) Protecting children is everyone's business: National framework for protecting Australia's children 2009-2020. Available at:

www.coag.gov.au/coag meeting outcomes/20090430/docs/child protection fra mework.pdf>

Courtney, M. (2008) 'Use of secondary data to understand the experiences of care leavers: cross national comparisons.' In M. Stein and E.R. Munro (eds) Young People's Transitions from Care to Adulthood: International Research and Practice. London: Jessica Kingsley Publishers.

Davies, C. and Ward, H. (forthcoming) Safeguarding Children Across Services: Messages from research on identifying and responding to child maltreatment. London: Jessica Kingsley Publishers.

Fernandez, E. and Barth, R. (2010) How does Foster Care Work? International evidence and outcomes. London: Jessica Kingsley Publishers.

Finkelhor, D. (2008) Violence, crime and abuse in the lives of young people. Oxford: Oxford University Press. 
Fluke, J. (2010) 'Child maltreatment data: Update from the National Child abuse and Neglect data system.' In J. Gray (ed) World Perspectives on Child Abuse Ninth Edition. Colorado: International Society for the Prevention of Child Abuse and Neglect.

Fox, J.A. and Zawitz, J.A. (2007) Homicide trends in the United States. Washington DC: US Department of Justice.

Gilbert, R., Kemp, A., Thoburn, J., Sidebotham, P., Radford, L., Glaser, D. and MacMillan, H.L. (2009) 'Recognising and responding to child maltreatment.' The Lancet 372, 167-80.

Hantrais, L. (2009) International Comparative Research: Theory, methods and practice. Basingstoke: Palgrave Macmillan.

Harries, M. and Clare, M. (2002) Mandatory reporting of child abuse: Evidence and options. Perth: Discipline of Social Work and Social Policy, University of Western Australia.

Hetherington, R. and Katz, I. (2006) 'Cooperation and Communicating: A European perspective on integrating services for children.' Child Abuse Review 15, 429-439.

HM Government (2010) Working Together to safeguard Children: A guide to inter-agency working to safeguard and promote welfare for children. London: The Stationery Office.

Holmes, L., Munro, E.R. and Soper, J. (2010) Calculating the cost and capacity implications for local authorities implementing the Laming (2009)

recommendations. London: Local Government Association. Available at: http://www.lga.gov.uk/lga/aio/9387423

Hymel, K.P. (2006) 'Distinguishing sudden infant death syndrome from child abuse fatalities.' Paediatrics 118, 421-27.

ISPCAN (2010) World Perspectives on Child Abuse: Ninth edition. J. Gray (ed). USA: International Society for Prevention of Child Abuse and Neglect.

Iwaniec, D. (1995) The Emotionally Abused and Neglected Child. Chichester: Wiley.

Lonne, B., Parton, N. and Thomson, J. (2008) Reforming child protection. London: Routledge.

Mathews, B. and Kenny, M.C. (2008) 'Mandatory reporting legislation in the United States, Canada and Australia: A cross-jurisdictional review of key features, differences and issues.' Child Maltreatment 13, 50-63. 
Munro, E. R., Stein, M. and Ward, H. (2005) 'Comparing how different social, political and legal frameworks support or inhibit transitions from public care to independence in Europe, Israel, Canada and the United States.' International Journal of Child Welfare 4,191-201.

Munro, E.R. and Stein, M. (2008) 'Comparative Exploration of Care Leavers Transitions to Adulthood: An Introduction.' In M. Stein and E.R. Munro (eds) Young People's Transitions from Care to Adulthood: International Research and Practice. London, Jessica Kingsley Publishers.

National Institute for Health and Welfare (2009) Child Welfare 2008. Helsinki: Official Statistics of Finland. Available at:

http://www.stakes.fi/EN/tilastot/statisticsbytopic/childhoodandfamily/childwelfare.h tm

OECD (2010) OECD Family Database. Paris: OECD Headquarters. Available at: http://www.oecd.org/document/4/0,3746,en_2649_34819_37836996_1_1_1_1,00 .html

Committee on the Rights of the Child (2003) Second periodic reports of State parties due in 1999 (Canada). (CRC/C/83/Add.6). 12 March 2003. p36. Available at: http://tb.ohchr.org/default.aspx

Committee on the Rights of the Child (2004) Second and third periodic reports of State parties due in 1998 and 2003 (Australia). (CRC/C/129/Add.4). 29

December 2004. p33. Available at: http://tb.ohchr.org/default.aspx

Committee on the Rights of the Child (2009) Fourth periodic reports of State parties due in 2008 (Norway). (CRC/C/NOR/4). 11 May 2009. p174. Available at: http://tb.ohchr.org/default.aspx

Committee on the Rights of the Child (2010a) Fourth periodic reports of State parties due in 2008 (Denmark). (CRC/C/DNK/4). 22 January 2010. p147.

Available at: http://tb.ohchr.org/default.aspx

Committee on the Rights of the Child (2010b) Fourth periodic reports of State parties due in 2008 (Finland). (CRC/C/FIN/4). 26 May 2010. p181. Available at: http://tb.ohchr.org/default.aspx

Pritchard, C. and Williams, R. (2010) 'Comparing Possible 'Child-Abuse-RelatedDeaths' in England and Wales with the Major Developed Countries 1974-2006: Signs of Progress?' British Journal of Social Work 40, 1700-1718.

Public Health Agency of Canada (2010) Canadian Incidence Study of Reported Child Abuse and Neglect - 2008: Major Findings. Ottawa: Public health Agency of Canada.

Rees, G., Hicks, S., Gorin, S. and Stein, M. (forthcoming) Adolescent Neglect: Research, Policy and Practice. London: Jessica Kingsley Publishers. 
Sandbaek, M., Bakketeig, E. and Einarsson, H. (2008) Norwegian national and local policies on prevention of violence against children. Oslo: NOVA.

Sedlak, A.J. and Broadhurst, D.D. (1996) Executive summary of the third national incidence study of child abuse and neglect. Washington, DC: U.S.

Department of Health and Human Services.

Sidebotham, P. and Fleming, P. (2007) Unexpected Death in Childhood. Germany: Wiley-UCH.

Stein, M. and Munro, E.R. (eds) (2008) Young People's Transitions from Care to Adulthood: International Research and Practice. London: Jessica Kingsley Publishers.

Thoburn, J. (2007) Globalisation and child welfare: some lessons from a crossnational study of children in out-of-home care. Norwich: University of East Anglia. Available at:

http://www.uea.ac.uk/polopoly_fs/1.103398!globalisation\%201108.pdf

Trocmé, N., McPhee, D., Kwan Tam, K., Hay, T. (1994) Ontario Incidence Study of Reported Child Abuse and Neglect. Toronto: Institute for the Prevention of Child Abuse.

U.S. Department of Health and Human Services, Administration for Children and Families, Administration on Children, Youth and Families, Children's Bureau. (2010) Child Maltreatment 2008. Available at:

http://www.childwelfare.gov/systemwide/statistics/can.cfm

UNICEF (2003) A league table of child maltreatment deaths in rich nations. Innocenti Report Card Number 5. Florence: UNICEF Innocent Research Centre.

UNICEF (2007) Child Poverty in Perspective: An overview of child well-being in rich countries, Innocenti Report Card 7, 2007. Florence: UNICEF Innocenti Research Centre. Available at: http://www.unicef.org/media/files/ChildPovertyReport.pdf

Ward, H. (2008) 'Legal and Policy Frameworks.' In M. Stein and E.R. Munro (eds) Young People's Transitions fro Care to Adulthood: International Research and Practice. London: Jessica Kingsley Publishers.

Ward, H., Holmes, L. and McDermid, S. (2008) Costs and Outcomes of Services Provided to Children in Need. Report to DCSF. Centre for Child and Family Research: Loughborough University.

WHO (2008) Health for All Database (HFA-DB). Copenhagen: WHO Regional Office of Europe. Available at: http://www.euro.who.int/en/what-we-do/data-andevidence/databases/european-health-for-all-database-hfa-db2

WHO and ISPCAN (2006) Preventing child maltreatment: a guide to taking action and generating evidence. Geneva: World Health Organization and International 
Society for the Prevention of Child Abuse and Neglect. Available at: http://whqlibdoc.who.int/publications/2006/9241594365_eng.pdf 
Ref: DFE-RR083

ISBN: 978-1-84775-855-2

(c) Childhood Wellbeing Research Centre

February 2011 